DOI: 10.32089/WBH.PHW.2021.2(276).0006

orcid.org/0000-0001-6793-3217

\title{
Marcin Arbuz
}

Wojskowe Biuro Historyczne im. gen. broni Kazimierza Sosnkowskiego

\section{Działania bojowe 315 Dywizjonu Myśliwskiego „Dęblińskiego” podczas operacji „Overlord” 6 czerwca - 7 lipca 1944 r.}

\begin{abstract}
The article describes the preparations and the role of No. 315 Squadron (Dęblin) during Operation "Overlord". The unit, which was assigned to No. 133 Wing of the 2nd Tactical Air Force (2nd TAF) was primarily deployed in a close air support role over Normandy, focusing mainly on enemy targets in both front-line areas and deep behind enemy lines. In the first half of July 1944 the squadron was transferred from the 2nd TAF to the Air Defence of Great Britain command, in order to counteract the threat posed by German V-1 "flying bombs".

6 czerwca 1944 r., od udanego desantu wojsk alianckich w Normandii przeprowadzonego pod kryptonimem „Neptun”, rozpoczęła się zakończona sukcesem operacja „Overlord”. Przełamanie Wału Atlantyckiego i utworzenie kolejnego frontu w Europie było owocem wielomiesięcznych przygotowań i efektem połączonych wysiłków zjednoczonych w alianckim obozie sił zbrojnych. Wśród aliantów biorących udział w operacji, znaczący wkład wnieśli także żołnierze Polskich Sił Zbrojnych na Zachodzie (PSZ), w tym lotnicy Polskich Sił Powietrznych (PSP). Pięć polskich dywizjonów myśliwskich oraz jeden dywizjon bombowy włączonych w strukturę 2nd Tactical Air Force (2nd TAF) ${ }^{1}$ wzięło bezpośredni udział
\end{abstract}

W literaturze przedmiotu najczęściej można spotkać dwie wersje tłumaczenia terminu 2nd Tactical Air Force jako 2 Lotnictwo Współpracy lub 2 Lotnictwo Taktyczne. Aby 
w działaniach bojowych nad Normandią latem 1944 r. 315 Dywizjon Myśliwski (DM) „Dębliński”, wchodzący w skład 133 Skrzydła Myśliwskiego (SM) 2nd TAF, od 6 czerwca do 7 lipca 1944 r. wykonywał zadania bojowe nad północną Francją atakując cele naziemne oraz zwalczając przeciwnika w powietrzu. Na początku lipca jednostka została przesunięta do struktur Powietrznej Obrony Wielkiej Brytanii (Air Defence of Great Britain - ADGB) w celu przeciwdziałania atakom "latających bomb” V1 i rozpoczęła nowy okres służby. Dotychczas powstało niewiele prac szczegółowo opisujących działania bojowe polskich dywizjonów w konkretnych kampaniach prowadzonych w czasie II wojny światowej. Kanoniczne dzieła, jak np. wydane w 1969 r. Lotnictwo Polskie w Wielkiej Brytanii ${ }^{2}$ autorstwa Franciszka Kalinowskiego czy w dużej mierze podsumowujące obecny stan wiedzy na temat PSP dwutomowe wydawnictwo autorstwa Jerzego B. Cynka pt. Polskie Sily Powietrzne w wojnie 1939$1945^{3}$ wydane w Polsce w latach 2001-2002, mają charakter syntetyczny. Kilka dywizjonów PSP doczekało się wydanych po polsku monografii, w których można odnaleźć opisy udziału tych jednostek w konkretnych kampaniach, ${ }^{4}$ jednak prac w całości poświęconych udziałowi wybranych jednostek PSP w poszczególnych operacjach bojowych jest zdecydowanie najmniej. ${ }^{5}$

uniknąć wątpliwości, w całym tekście zastosowano oryginalną nazwę bądź jej skrót 2nd TAF.

2 Zob. Franciszek Kalinowski, Lotnictwo Polskie w Wielkiej Brytanii (Paryż: Wyd. Instytut Literacki, 1969).

3 Zob. Jerzy B. Cynk, Polskie Sity Powietrzne w wojnie 1939-1945, t. 1-2 (Gdańsk: Wyd. Aj-Press, 2001-2002).

4 Zob. Łukasz Jaśkiewicz, 300 Dywizjon Bombowy „Ziemi Mazowieckiej” (Oświęcim: Napoleon V, 2013); Piotr Hodyra, 301 Dywizjon Bombowy 1940-1943 (Warszawa: Ofic. Wyd. Alma-Press, 2016); Grzegorz Śliżewski, Wojna na pociski i pisma. 302 „Poznański” Dywizjon Myśliwski w 1940 roku (Oświęcim: Napoleon V, 2019); Józef Zieliński, 303 Dywizjon Myśliwski Warszawski im. Tadeusza Kościuszki (Warszawa: Bellona, 2003); Jaśkiewicz, 304 Dywizjon Bombowy „Ziemi Śląskiej im. Ks. Józefa Poniatowskiego” (Oświęcim: Napoleon V, 2018); Zieliński, 305 Dywizjon Bombowy Ziemi Wielkopolskiej i Lidzkiej im. Marszałka Józefa Piłsudskiego (Warszawa: Bellona, 2004); Wojtek Matusiak, 306 Dywizjon Myśliwski Toruński (Warszawa: Bellona, 2003); Robert Gretzyngier, 307 Dywizjon Myśliwski Nocny „lwowskich Puchaczy” (Warszawa: Bellona, 2006); Jacek Kutzner, 308. Dywizjon Myśliwski „Krakowski” (Warszawa: Ofic. Wyd. Rytm, 2011); Kutzner, 315. Dywizjon Myśliwski „Dębliński” (Warszawa: Ofic. Wyd. Rytm, 2013); Marek Wroński i Robert E. Stolarski, Waleczne „Kubusie”. Monografia 663 Dywizjonu samolotów artylerii, t. 1-2 (Londyn-Tarnowskie Góry: Wyd. Instytutu Tarnogórskiego i Muzeum Instytutu Tarnogórskiego, 1999); Zieliński, 663. Dywizjon Samolotów Artylerii (Warszawa: Wyd. Lampart, 2000).

5 Zob. Kutzner, 303. Dywizjon Myśliwski w bitwie o Wielka Brytanię (Warszawa: Ofic. Wyd. Rytm, 2010); Śliżewski, Nad krwawiącymi liśćmi klonu. Polscy piloci myśliwscy w operacji „Jubilee" (Dieppe, 19 sierpnia 1942 roku) (Oświęcim: Napoleon V, 2018); Śliżewski i Grzegorz 
Teksty związane $\mathrm{z}$ tematem omawianym $\mathrm{w}$ niniejszym artykule zwykle miały charakter popularnonaukowy. W $1983 \mathrm{r}$. ukazała się praca jednego z uczestników wydarzeń - Wacława Króla - pt. Polskie skrzydła w inwazji na Francję. ${ }^{6}$ Książka oparta na doświadczeniach autora oraz dostępnych wówczas źródłach opisywała udział poszczególnych polskich dywizjonów w działaniach bojowych w trakcie operacji „Overlord”. Poza pewnymi wyjątkami ${ }^{7}$ najwięcej tekstów poświęconych działaniom bojowym dywizjonów PSP podczas inwazji ukazało się w czasopismach i magazynach o tematyce lotniczej. ${ }^{8}$ Niniejszy artykuł ma za zadanie wypełnić lukę w dotychczasowych badaniach dotyczących omawianego tematu i w ograniczonych objętościowo ramach maksymalnie szczegółowo, dzień po dniu, ukazać przebieg udziału 315 DM „Dęblińskiego” w operacji „Overlord”.

\section{DM „Dębliński” i 2nd TAF}

315 DM „Dębliński” sformowano 21 stycznia 1941 r. na stacji Królewskich Sił Powietrznych (RAF) Acklington. Był to piąty dzienny dywizjon myśliwski PSP utworzony w Wielkiej Brytanii. Etap formowania oraz szkolenia jednostki zakończył się wraz z przeniesieniem jej na stację RAF Speke. 13 marca $1941 \mathrm{r}$. dywizjon wylądował na nowym lotnisku, a 18 marca osiągnął gotowość operacyjną. ${ }^{9}$ Od momentu sformowania w 1941 r. do końca 1943 r. jednostka wykonała 3506 samolotozadań w łącznym czasie 5325 godzin. ${ }^{10} \mathrm{~W}$ okresie tym

Sojda, Cyrk Skalskiego (Piekary Śląskie-Warszawa: ZP Grupa, 2009); Sojda, Śliżewski i Hodyra, Ci cholerni Polacy! Polskie Sity Powietrzne w Bitwie o Anglie (Warszawa: Ofic. Wyd. Alma-Press, 2016).

6 Zob. Wacław Król, Polskie skrzydła w inwazji na Francję (Warszawa: Wyd. Ministerstwa Obrony Narodowej, 1983).

7 Zob. Piotr Sikora, Bitwy polskiego lotnictwa 1918-1945 (Warszawa: Ofic. Wyd. Alma-Press, 2016), 321-335.

8 Zob. Aleksander Klemens Gabszewicz i Zygmunt Witymir Bieńkowski, „Lotnictwo Myśliwskie 2. TAF," Lotnictwo Aviation International (LAI), nr 15 (1992), 38-40; Gabszewicz i Bieńkowski, „Lotnictwo Myśliwskie 2. TAF (część 2),” LAI, nr 16 (1992), 31-33; Cynk, „Polskie lotnictwo inwazyjne," Skrzydlata Polska, nr 6 (1994), 46-52; Franciszek Grabowski, „D+1, wielki dzień 133 Skrzydła (część 1)," Magazyn Historyczny „Militaria i fakty”, nr 2 (2007), 28-41; Grabowski, „D+1, wielki dzień 133 Skrzydła (część 2),” Magazyn Historyczny „Militaria i fakty”, nr 4 (2007), 4-12; Jacek Przybył, „Mustang i szachownica. Zarys działań wojennych 133. Skrzydła Myśliwskiego," Technika Wojskowa Historia, nr 4 (2012), 52-65; Matusiak, „Polskie formacje lotnicze w inwazji na Normandię," Biuletyn IPN, nr 6 (2019): 89-101.

9 The National Archives (dalej: TNA), Operations Record Books (dalej: ORB), AIR-27-1699-1, No. 315 Squadron, b.m., b.d., 1-4; Matusiak, Gretzyngier i Wiśniewski, 315 Squadron (Polish) Squadron „Dęblin”, tłum. Matusiak (Sandomierz: Stratus, 2004), 5-6.

10 Cynk, Polskie Sity, 2:755. 
piloci zapisali na koncie dywizjonu 38 pewnych i 14 prawdopodobnych zestrzeleń oraz zgłosili 21 uszkodzeń samolotów nieprzyjaciela. ${ }^{11} \mathrm{~W}$ tym samym czasie zginęło lub poległo 27 pilotów, a 6 trafiło do niewoli. ${ }^{12}$

Rok 1944 dla lotników 315 DM, oprócz rutynowych zadań, miał upłynąć głównie pod znakiem uczestnictwa w operacji „Overlord”, a także przeciwdziałania atakom „latających bomb” V1. Najpierw jednak nastąpiła prowadzona od połowy 1943 r. reorganizacja brytyjskiego lotnictwa wojskowego. Objęła ona także dywizjony PSP i spowodowała, że 315 DM w listopadzie 1943 r. został włączony do 133 SM (do 4 października 1943 r. II SM), wchodząc tym samym w strukturę 2 nd TAF. ${ }^{13}$

2nd TAF powołano do życia 1 czerwca $1943 \mathrm{r}^{14}$ Formacja lotnictwa taktycznego utworzona w celu wsparcia wojsk alianckich biorących udział w inwazji na kontynent powstała $\mathrm{z}$ wybranych jednostek lotniczych RAF, państw Wspólnoty Brytyjskiej oraz krajów okupowanych. ${ }^{15}$ Do głównych zadań 2nd TAF miało należeć rozpoznanie lotnicze, bezpośrednie wsparcie wojsk lądowych oraz izolowanie pola walki. Założono, że cele stawiane przed lotnictwem taktycznym w głównej mierze realizować będą samoloty myśliwskie, myśliwsko-rozpoznawcze i lekkie samoloty bombowe. W składzie 2nd TAF oprócz Dowództwa (HQ) ostatecznie znalazły się 2, 83, 84 i 85 Grupa. Dodatkowo lotnictwo transportowe w postaci 38 Grupy (Powietrznodesantowej) oraz 46 Grupy (Transportowej) zostało bezpośrednio podporządkowane Alianckim Ekspedycyjnym Siłom Powietrznym (Allied Expeditionary Air Force). ${ }^{16} \mathrm{~W}$ ramach 84 Grupy 4 października 1943 r., rozpoczęto formowanie 18 Sektora Myśliwskiego, w skład którego weszły dwa polskie SM. Włączone do 2nd TAF I oraz II SM otrzymały odpowiednio numery 131 i 133 . Trzecie, brytyjskie skrzydło włączone do sektora w marcu $1944 \mathrm{r}$. oznaczono numerem $135 .{ }^{17} 18$ Sektor, początkowo dowodzony przez G/Cpt ${ }^{18}$ Tadeusza Rolskiego, od 25 lu-

\footnotetext{
11 Matusiak, Gretzyngier i Wiśniewski, 315, 110-113.

12 Ibid., 108-109.

13 Cynk, Polskie, 2:676.

14 Christopher Shores i Chris Thomas, 2nd Tactical Air Force. Volume one Spartan to Normandy June 1943 to June 1944, t. 1 (Horsham: Classic Publications, 2004), 16.

15 Matusiak, Polskie, 90.

16 Shores i Thomas, 2nd, 1:120-121.

17 Cynk, Polskie, 2:393.

18 W tekście stosowane są brytyjskie stopnie wojskowe, które mogły - ale nie musiały odpowiadać polskim stopniom wojskowym. W przypadku lotników PSP oraz RAF stosowano stopnie stałe i funkcyjne. Na przykład lotnik posiadający polski stopień porucznika, mógł mieć stopień funkcyjny Flight Lieutenant (F/Lt) (kapitan) i na odwrót. Poniżej użyte w tekście brytyjskie stopnie wojskowe i ich polskie odpowiedniki: Sgt Sergeant - sierżant, F/Sgt Flight Sergeant - starszy sierżant, W/O Warrant Officer - chorąży, P/O Pilot Officer
} 
tego 1944 r. przez cały okres inwazji znajdował się pod dowództwem G/Cpt Aleksandra Gabszewicza. ${ }^{19}$

W strukturze 18 Sektora znalazły się również Polowe Porty Lotnicze (PPL), którym były podporządkowane poszczególne skrzydła. Organizacja nowej formacji zmieniała także zasady działania systemu obsługi technicznej. W miejsce eskadr technicznych, przyporządkowanych i obsługujących konkretne dywizjony, wprowadzono eszelony obsługowe niezwiązane z konkretnymi jednostkami, a obszarami bazowania. ${ }^{20}$ Przeorganizowano także oddziały łączności. ${ }^{21}$ Wszystkie te zmiany miały przyczynić się do wysokiej mobilności i umożliwić ciągłość działania w warunkach dynamicznie przesuwającego się rejonu operacyjnego. Istotną zmianą było także przezbrojenie wybranych jednostek w samoloty pozwalające na jak najskuteczniejsze wykonywanie zadań stawianych przed lotnictwem taktycznym. Dlatego też m.in. polskie dywizjony $133 \mathrm{SM}$ zostały uzbrojone $\mathrm{w}$ myśliwce North American $\mathrm{Mu}-$ stang III. W przededniu operacji „Overlord” skład polskich skrzydeł 18 Sektora wyglądał następująco: 131 SM dowodzone przez W/Cdr Juliana Kowalskiego (uzbrojone w samoloty Supermarine Spitfire IX): 302 DM „Poznański”, 308 DM „Krakowski” oraz 317 DM „Wileński”; 133 SM dowodzone przez W/Cdr Stanisława Skalskiego (uzbrojone w samoloty North American Mustang III): 306 DM „Toruński”, 315 DM „Dębliński” oraz 129 DM RAF „Mysore”; 135 SM dowodzone przez W/Cdr Raymonda H. Harriesa (uzbrojone w samoloty Supermarine Spitfire IX): 222 DM RAF, belgijski ${ }^{22} 349$ DM RAF i 485 DM Królewskich Nowozelandzkich Sił Powietrznych. ${ }^{23}$ Poza polskimi dywizjonami myśliwskimi, które zasiliły 84 Grupę, do 138 SM 2 Grupy 2nd TAF przydzielono polski 305 Dywizjon Bombowy „Ziemi Wielkopolskiej”.

- podporucznik, F/O Flying Officer - porucznik, F/Lt Flight Lieutenant - kapitan, S/Ldr Squadron Leader - major, W/Cdr Wing Commander - podpułkownik, G/Cpt Group Captain - pułkownik, AVM Air Vice Marshal - generał brygady; zob. Cynk, Polskie, 1:XXII-XXIII.

19 Ibid., 2:393.

20 Ibid.

21 Ibid., 2:392-393.

22 Na podstawie ustaleń dotyczących współpracy wojskowej poczynionych pomiędzy rządami Belgii i Wielkiej Brytanii belgijskich lotników włączano do ochotniczej rezerwy RAF i kierowano do wybranych dywizjonów RAF lub Południowoafrykańskich Sił Powietrznych. Utworzono także dwie jednostki w całości złożone z Belgów. 12 XI 1941 r. w Wielkiej Brytanii sformowano 350 DM RAF, zaś 10 XI 1942 r. w Nigerii 349 DM RAF. Zob. Alan Brown, Airmen in Exile. The Allied Air Forces in the Second World War (Phoenix Mill-Thrupp-Stroud: Sutton Publishing Ltd., 2000), 181-191.

23 Shores i Thomas, 2nd, 1:120-121; Cynk, Polskie, 2:676; Shores i Clive Williams, Aces High. A Tribute to the Most Notable Fighter Pilots of the British and Commonwealth Forces in WWII (London: Grub Street, 1994), 315.

24 Shores i Thomas, 2nd, 1:120. 
W ramach przygotowań do inwazji w strukturze RAF zaszły też inne zmiany. Między innymi dotychczasowe Dowództwo Lotnictwa Myśliwskiego RAF (RAF Fighter Command) zostało przekształcone w ADGB. W skład ADGB weszły dwa polskie dywizjony myśliwskie: 303 DM „Warszawski” im. Tadeusza Kościuszki (wyposażony w samoloty Supermarine Spitfire V) oraz 316 DM „Warszawski” (wyposażony w myśliwce North American Mustang III). Te dwa dywizjony stanowiły bezpośredni odwód odpowiednio dla 131 i 133 SM, co nie zwalniało ich z ciągłego wykonywania rutynowych zadań. Ponadto w strukturze ADGB znalazły się 307 DM Nocny „Lwowski” oraz 309 Dywizjon Myśliwsko-Rozpoznawczy „Ziemi Czerwieńskiej”.

\section{Przygotowania}

Na początku 1944 r. w 315 DM, podobnie jak w innych polskich dywizjonach 131 i 133 SM, nastąpiła zmiana dowódcy. 15 lutego 1944 r. w miejsce S/Ldr Jerzego Popławskiego dowództwo jednostki objął S/Ldr Eugeniusz Horbaczewski, przez kolegów nazywany „Dziubkiem”. ${ }^{26}$ Lotnik z bardzo dużym doświadczeniem bojowym, nabytym m.in. podczas służby w Polskim Zespole Myśliwskim w Afryce Północnej czy też jako dowódca 43 DM RAF, miał poprowadzić $315 \mathrm{DM}$ do walki nad Normandią. ${ }^{27}$

28 marca 1944 r. piloci 315 DM powrócili na lotnisko bazowania do Heston z ćwiczeń ogniowych (Armament Practice Camps) w Llanbedr w Walii, gdzie szkolili się od 24 marca. Było to drugie szkolenie tego typu, pierwsze lotnicy przechodzili od 19 grudnia 1943 r. do 1 stycznia $1944 \mathrm{r}^{28}$ Tego samego dnia $\mathrm{z}$ dowództwa 133 SM nadszedł rozkaz o przeniesieniu skrzydła na nowe lotnisko w Coolham w hrabstwie West Sussex. ${ }^{29}$ Zgodnie z rozkazem 1 kwietnia rozpoczęto przenosiny na lotnisko Coolham $\mathrm{ALG}^{30}$. Ściśle

25 Matusiak, Polskie, 94-95.

26 Matusiak, Gretzyngier i Wiśniewski, 315, 105.

27 S/Ldr Eugeniusz Horbaczewski po powrocie ze śródziemnomorskiego TDW, gdzie dowodził $43 \mathrm{DM}$, miał objąć dowództwo 303 DM. Zachorował jednak na żółtaczkę, a jego miejsce zajął S/Ldr Tadeusz Koc. Po powrocie do zdrowia Horbaczewski został wyznaczony na dowódcę 315 DM „Dęblińskiego". Jednostką dowodził od 15 II 1944 r. do 18 VIII 1944 r., kiedy to poległ podczas walki powietrznej nad Francją. Matusiak, „Dziubek u Kosynierów (część 2)," Lotnictwo, nr 6 (2006), 64; Matusiak, Gretzyngier i Wiśniewski, 315, 105.

28 Shores i Thomas, 2nd, 1:53.

29 TNA, ORB, AIR-27-1701-7, No. 315 Squadron, b.m., b.d., 1; Instytut Polski i Muzeum im. gen. Sikorskiego (dalej: IPiMS), 315 Dywizjon Myśliwski (dalej: 315 DM), LOT.A.V.53/50, Dziennik Działań Dywizjonu 1 IV 1944 r. - 4 IV 1945 r., b.m., b.d., b.p.

$30 \quad$ Advanced Landing Ground (ALG) - tymczasowe lotnisko polowe przygotowane w celu obsługi jednostek lotniczych biorących udział w operacji „Overlord”. W 1942 r. brytyjskie Ministerstwo Lotnictwa wybrało 72 ewentualne lokalizacje przyszłych lotnisk polowych. 
polowe warunki w nowym miejscu bazowania miały przygotować personel latający i naziemny do realiów frontowych. Nocowanie w namiotach i operowanie $\mathrm{z}$ trawiastych pasów startowych utwardzonych metalową siatką miało stać się teraz normą. ${ }^{31}$ Pod koniec marca 1944 r. kilku pilotów dywizjonu wykonało pierwsze loty na samolotach North American Mustang III. $\mathrm{W}$ kwietniu proces przezbrajania jednostki na nowe myśliwce nabrał tempa. Treningi prowadzono na lotnisku Coolham lub oddalonym o ok. $23 \mathrm{~km}$ na południowy zachód lotnisku Ford. Okres przeszkolenia pilotów dywizjonu nie był pozbawiony drobnych wypadków, jednak na początku zasadniczo przebiegał bez przeszkód. Po opanowaniu obsługi samolotu, startów, lądowań i lotów w rejonie lotnisk, rozpoczęto treningi bojowe polegające przede wszystkim na atakowaniu celów naziemnych przy użyciu bomb i uzbrojenia pokładowego. W pierwszej połowie kwietnia do dywizjonu dołączyli też nowi piloci: P/O Roman Brygider i W/O Tadeusz Tamowicz - obu przydzielono do eskadry A..$^{32}$

Z kolei od 19 kwietnia 315 DM brał udział w ćwiczeniach „Lambourne"33 polegających na przetrenowaniu i sprawdzeniu współpracy lotnictwa i jednostek lądowych pod kątem bliskiego wsparcia (ang. close support) opartego na stałej łączności radiowej. 19 kwietnia przyniósł też pierwszą stratę na nowym myśliwcu - w trakcie treningu zginął niedawno przybyły do jednostki P/O Brygider. ${ }^{34} \mathrm{~W}$ drugiej połowie kwietnia do dywizjonu dołączyli F/Sgt Antoni Kępczyński, przydzielony do eskadry B, oraz F/O Kazimierz Wünsche przydzielony do eskadry A. ${ }^{35}$ Pierwsze zadanie bojowe na

Ostatecznie powstały 23 lotniska tego typu. Paul Hamlin i Ann Davies, Coolham airfield remembered. Memories and anecdotes of a Sussex D-Day Fighter Station and Village (Horsham: Paul Hamlin, 1996), 3.

31 TNA, ORB, AIR-27-1701-7, No. 315 Squadron, b.m., b.d., 1; IPiMS, 315 DM, LOT.A.V.53/50, Dziennik Działań Dywizjonu 1 IV 1944 r. - 4 IV 1945 r., b.m., b.d., b.p.

32 TNA, ORB, AIR-27-1701-5, No. 315 Squadron, b.m., b.d., 3; AIR-27-1701-7, No. 315 Squadron, b.m., b.d., 1; IPiMS, 315 DM, LOT.A.V.53/50, Dziennik Działań Dywizjonu 1 IV 1944 r. - 4 IV 1945 r., b.m., b.d., b.p.

33 W opracowaniach dotyczących omawianego tematu można spotkać się też z nazwą „Lambourn”. W dokumentach źródłowych dotyczących dywizjonów 133 SM występuje zaś nazwa „Lambourne”. TNA, ORB, AIR-27-1674-7, No. 306 Squadron, b.m., b.d., 3; AIR-27-934-61, No. 129 Squadron, b.m., b.d., 9-10; Terry Copp, The Brigade: The Fifth Canadian Infantry Brigade in World War II (Machanicsburg: Stackpole Books, 2007), 39; Cynk, Polskie Siły, 2:408-409.

34 Gretzyngier et al., Ku czci polegtych lotników 1939-1945 (Warszawa: Agencja Lotnicza Altair, 2006), 418-419; Kelvin Youngs, „19.04.1944 No. 315 Squadron Mustang III FX895 P/O. Brygider," Aircrew Remembered, dostęp styczeń 25, 2021, http://aircrewremembered. com/brygider-roman.html.

35 TNA, ORB, AIR-27-1701-7, No. 315 Squadron, b.m., b.d., 2; IPiMS, 315 DM, LOT.A.V.53/50, Dziennik Działań Dywizjonu 1 IV 1944 r. - 4 IV 1945 r., b.m., b.d., b.p. 
nowym typie samolotu przeprowadzono 26 kwietnia $1944 \mathrm{r}^{36} 29$ kwietnia zaś kolejne, $\mathrm{w}$ trakcie którego $\mathrm{w}$ wyniku ognia artylerii przeciwlotniczej trafiony w kabinę został samolot dowódcy dywizjonu S/Ldr Horbaczewskiego. Ranny w głowę pilot bezpiecznie doleciał do bazy i po profilaktycznej wizycie w szpitalu powrócił do służby. ${ }^{37} 4$ maja $1944 \mathrm{r}$. w ramach bezpośrednich przygotowań do inwazji 315 DM wziął udział w ćwiczeniach "Fabius”. ${ }^{38}$ Ciągły trening w maju zaczął przeplatać się z kolejnymi zadaniami bojowymi, które niestety przyniosły również straty. 20 maja podczas ataku z lotu nurkowego zginął F/O Stanisław Caliński. ${ }^{39} 25$ maja w trakcie zadania typu „Ranger” ${ }^{40}$ piloci 315 DM wpisali na konto jednostki jako zestrzelone na pewno dwa samoloty Arado Ar 96 należące do 3/JG105 ${ }^{41} .^{42}$

\section{Czerwiec 1944}

2 czerwca 1944 r. w siedzibie dowództwa 2nd TAF w Uxbridge odbyła się odprawa, w której uczestniczyli m.in. dowódca 18 Sektora Myśliwskiego

36 TNA, ORB, AIR-27-1701-7, No. 315 Squadron, b.m., b.d., 1; AIR-27-1701-8, No. 315 Squadron, b.m., b.d., 3; IPiMS, 315 DM, LOT.A.V.53/50, Dziennik Działań Dywizjonu 1 IV 1944 r. - 4 IV 1945 r., b.m., b.d., b.p.

37 TNA, ORB, AIR-27-1701-7, No. 315 Squadron, b.m., b.d., 1; AIR-27-1701-8, No. 315 Squadron, b.m., b.d., 3; IPiMS, 315 DM, LOT.A.V.53/50, Dziennik Działań Dywizjonu 1 IV 1944 r. - 4 IV 1945 r., b.m., b.d., b.p.

38 „Fabius” - kryptonim ćwiczeń przeprowadzonych przez wojska sprzymierzonych w pierwszej połowie maja 1944 r. Plan manewrów zakładał dokładną symulację desantu morskiego, który miał nastąpić w czerwcu na normandzkich plażach. Rejonem operacyjnym ćwiczeń był obszar południowego wybrzeża Anglii pomiędzy Portsmouth a Brighton, dokładnie „naprzeciwko” przyszłego rejonu operacji; Christopher D. Yung, Gators of Neptune. Naval Amphibious planning for the Normandy Invasion (Annapolis: Naval Institute Press, 2006), 153.

39 TNA, ORB, AIR-27-1701-9, No. 315 Squadron, b.m., b.d., 3; IPiMS, 315 DM, LOT.A.V.53/3a, Kronika Dywizjonu 21 I 1941 r. - 13 VI 1944 r., b.m., b.d., b.p.; LOT.A.V.53/50, Dziennik Działań Dywizjonu 1 IV 1944 r. - 4 IV 1945 r., b.m., b.d., b.p.; Gretzyngier et al., Ku czci, 429.

40 „Ranger” - typ zadania realizowany głęboko nad terenem nieprzyjaciela przez swobodnie działającą formację myśliwską lub myśliwsko-bombową poszukującą wartych zaatakowania celów na trasie lotu. W zależności od potrzeb i okresu były to formacje złożone $\mathrm{z}$ kilku samolotów, całego dywizjonu, skrzydła lub jeszcze większego zgrupowania; zob. Cynk, Polskie, 1:XXIV; Shores i Thomas, 2nd, 1:10.

${ }_{41}$ Jagdgeschwader (JG) - w czasie II wojny światowej niemiecka, myśliwska jednostka lotnicza odpowiadająca brytyjskiemu skrzydłu. Dzieliła się na oznaczane cyframi rzymskimi Gruppen - odpowiedniki brytyjskich dywizjonów, a te z kolei na oznaczane numeracją arabską Staffeln - odpowiedniki brytyjskich eskadr.

42 TNA, ORB, AIR-27-1701-9, No. 315 Squadron, b.m., b.d., 4; AIR-27-1701-10, No. 315 Squadron, b.m., b.d., 7; Combat Reports (dalej: CR), AIR-50-125-65, No. 315 Squadron, b.m., b.d., 1-2; IPiMS, 315 DM, LOT.A.V.53/50, Dziennik Działań Dywizjonu, 1 IV 1944 r. 4 IV 1945 r., b.m., b.d, b.p.; LOT.A.V.53/3a, Kronika Dywizjonu 21 I 1941 r. - 13 VI 1944 r., b.m., b.d., b.p.; Wilhelm Ratuszyński, „25 May,” Polish Squadrons Remembered, dostęp styczeń 25, 2021, http://polishsquadronsremembered.com/315/44/may_25_44.html. 
- G/Cpt Gabszewicz oraz dowódcy 131 i 133 PPL, odpowiednio - W/Cdr Zbigniew Czaykowski oraz W/Cdr Tadeusz Nowierski. Podczas spotkania ujawniono planowany termin rozpoczęcia operacji „Overlord” - pierwotnie ustalony na 5 czerwca - oraz przekazano wstępne informacje dotyczące roli poszczególnych skrzydeł. ${ }^{43}$ Początek czerwca 1944 r. 315 DM wykorzystywał na przygotowywanie samolotów, na których wykonywano jedynie pojedyncze loty sprawdzające. Ostatnie zadania bojowe przed inwazją przeprowadzono 3 czerwca. Rankiem czterech pilotów wykonało lot typu „Ranger” w głąb Francji. Następnie po południu w sile całego dywizjonu przeprowadzono „Ramrod”44 964 w północno zachodniej Francji na zachód od Reenes (Ille-et-Vilaine ${ }^{45}$, w trakcie którego zaatakowano niemieckie składy paliwa znajdujące się w lesie Branguily w okolicach Pontivy (Morbihan). ${ }^{46}$

4 czerwca 1944 r. w Collham nie odbywano lotów. ${ }^{47}$ Lotnicy otrzymali polecenie pozostania na terenie bazy i przygotowania się do odprawy, która została przeprowadzona przez W/Cdr Skalskiego o godz. 14:30. Dowódca oprócz ogólnych informacji dotyczących inwazji zwrócił uwagę na zmiany w oznaczeniu samolotów. ${ }^{48} \mathrm{~W}$ celu ułatwienia rozpoznania swój-obcy wszystkie statki powietrzne biorące udział w operacji „Overlord” powinny posiadać biało-czarne pasy inwazyjne - każdy z trzech białych i dwóch czarnych pasów, wymalowanych na przemian na górnej i dolnej powierzchni obydwu skrzydeł oraz wokół tylnej części kadłuba, powinien mieć 18 cali $(45,7 \mathrm{~cm})$ szerokości $^{49} \mathrm{~W}$ poniedziałek 5 czerwca 1944 r. piloci $315 \mathrm{DM}$

43 Cynk, Polskie, 2:437; Józef Zieliński i Tadeusz Krzystek, Dowódcy dywizjonów Polskich Sił Powietrznych na Zachodzie, tłum. Paulina Stęplowska (Poznań: Wyd. Redakcja Czasopism WLOP przy współpracy z Domem Wyd. Bellona, 2002), 156; Wojciech Zmyślony, „Zbigniew Czaykowski," Polskie Siły Powietrzne w II wojnie światowej, dostęp maj 8, 2021, https:// www.polishairforce.pl/czaykowski.html.

44 „Ramrod” - typ zadania zwykle wykonywanego przez ugrupowanie samolotów uzbrojonych w bomby wraz z osłoną myśliwską, którego założeniem zazwyczaj było zaatakowanie konkretnego celu naziemnego. Odmianą tego zadania, ale wykonywanego na małej wysokości, był „Low Ramrod”. Zadania oznaczone tym samym numerem w zależności od okoliczności mogły być realizowane podczas kilku wylotów. Shores i Thomas, 2nd, 1:10; Cynk, Polskie Sity, 1:XXIV.

45 W nawiasach przy nazwach miejscowości umieszczono nazwy departamentów.

46 David G. Passmore, David C. Tunwell i Stephan Harrison, „Landscapes of Logistics: The Archaeology and Geography of WWII German Military Supply Depots in Central Normandy, North-west France," Journal of conflict Archeology 8, nr 3 (2013): 170.

47 TNA, ORB, AIR-27-1701-11, No. 315 Squadron, b.m., b.d., 1.; IPiMS, 315 DM, LOT.A.V.53/50, Dziennik Działań Dywizjonu 1 IV 1944 r. - 4 IV 1945 r., b.m., b.d., b.p.

48 Jakub Bargiełowski, Mustangiem w polu ognia (Warszawa: Stowarzyszenie Lotników Polskich, 2010), 94-95.

49 Zbigniew Kolacha i Jacek B. Żurek, North American P-51 Mustang, P-82 Twin Mustang, cz. 2 (Gdańsk: Wyd. Aj-Press, 1999), 11. 
wykonywali wyłącznie loty treningowe. ${ }^{50}$ Późnym popołudniem zaś do bazy 133 SM w Coolham przybył dowódca 2nd TAF, AM Arthur Coningham, $\mathrm{w}$ celu przeprowadzenia inspekcji dywizjonów i przekazania pilotom wiadomości, że inwazja nastąpi następnego dnia, tj. 6 czerwca. Zostały wówczas ogólnie omówione zadania, jakie będą wykonywać poszczególne dywizjony skrzydła. ${ }^{51}$ Odprawa dotycząca szczegółów operacji została przeprowadzona późnym wieczorem 5 czerwca. $^{52}$

\section{„Overlord”}

Ranek 6 czerwca był dla pilotów 315 DM sporym zawodem. Nie dane im było zobaczyć z powietrza pełnej skali operacji tak jak pilotom bratniego 131 SM. Na wykonanie swojego pierwszego zadania lotnicy dywizjonu musieli zaczekać kilkanaście godzin. „Ramrod” 976 (Glider Escort), w którym wzięło udział całe $133 \mathrm{SM}$, polegał na eskorcie złożonej z ponad pięciuset samolotów i szybowców desantowych wyprawy powietrznej pod kryptonimem „Mallard”. Na pokładzie szybowców znajdował się sprzęt oraz część żołnierzy brytyjskiej 6 Dywizji Powietrznodesantowej, stanowiących posiłki dla oddziałów utrzymujących mosty w Bénouville na kanale Caen oraz w Ranville nad rzeką Orne. Osłonę tej, ciągnącej się kilometrami, wyprawy zapewniało ponad 370 samolotów należących do RAF, państw Wspólnoty Brytyjskiej oraz krajów okupowanych i Sił Powietrznych Armii USA (United States Army Air Force). ${ }^{53}$ Mustangi 315 DM wzniosły się w powietrze o godz. 20:20 wspólnie z całym 133 SM prowadzonym przez W/Cdr Skalskiego. Pierwsze historyczne zadanie podczas dnia „D” wykonali S/Ldr Horbaczewski, F/O Andrzej Czerwiński, F/Sgt Bolesław Czerwiński, F/Sgt Kazimierz Siwek, F/O Wünsche, F/Lt Henryk Stefankiewicz oraz F/Lt Janusz Marciniak, F/Sgt Kazimierz Kijak, F/Sgt Tadeusz Jankowski, S/Ldr Mieczysław Wiórkiewicz, F/Lt Jerzy Polak i F/O Bożydar Nowosielski. Osłonę bezpośrednią grupy desantowej ze strony 133 SM stanowiły 306 DM oraz 315 DM, zaś 129 DM RAF zapewniał osłonę wysoką. Zadanie przebiegło bez przeszkód. Zauważono jedynie jeden wrogi samolot, który okazał się niemieckim myśliwcem Fw $190 .{ }^{54}$ Maszyna została przechwycona przez pilotów 129 DM RAF, F/Lt Allana J. Hancocka i W/O Williama E. Rig-

\footnotetext{
50 TNA, ORB, AIR-27-1701-11, No. 315 Squadron, b.m., b.d., 1.

51 Cwynar, Wspomnienia, 118.

52 IPiMS, 315 DM, LOT.A.V.53/3a, Kronika Dywizjonu 21 I 1941 r. - 13 VI 1944 r., b.m., b.d., b.p.

53 Rowley, D-Day, 64-65.

54 TNA, ORB, AIR-27-1701-11, No. 315 Squadron, b.m., b.d., 1; AIR-27-1701-12, No. 315 Squadron, b.m., b.d., 1; IPiMS, 315 DM, LOT.A.V.53/50, Dziennik Działań Dywizjonu 1 IV 1944 r. - 4 IV 1945 r., b.m., b.d., b.p.
} 
byego, którzy zgłosili ją jako zestrzeloną na pewno. Według raportu bojowego wrogi samolot został strącony ok. $24 \mathrm{~km}$ na południowy zachód od Caen..$^{55}$ Zwycięstwo to było pierwszym wpisanym na konto 133 SM podczas operacji „Overlord”. Myśliwce 315 DM lądowały w Coolham o godz. 22:00. ${ }^{56}$

7 czerwca 1944 r. ok. godz. 5:0577 skrzydło startowało do zadania „Ramrod” 980, które miało polegać na locie w głąb Francji w poszukiwaniu dogodnych do zbombardowania z lotu nurkowego celów. Trasa wiodła nad ArgentanBueil-Dreux i Sées. Na północny zachód od Argentan (Orne) piloci 315 DM rozpoznali i zaatakowali stację kolejową w rejonie Lignerolles (Orne). Zbombardowano też wiadukt kolejowy, kolumnę transportową oraz zarejestrowano bezpośrednie trafienie $\mathrm{w}$ torowisko $\mathrm{w}$ rejonie Chaumont (Orne).$^{58}$ Krótko po bombardowaniu w okolicy pojawił się niemiecki myśliwiec $\mathrm{w}$ porę zauważony przez polskich lotników. W wyniku walki powietrznej F/Lt Adam Sworniowski zgłosił pewne zestrzelenie samolotu Fw 190 ok. 5 km na zachód od Argen$\tan$ (Orne).$^{59}$ Było to pierwsze potwierdzone zwycięstwo wpisane na konto 315 DM podczas inwazji. Fw 190 zgłoszony przez F/Lt Sworniowskiego prawdopodobnie należał do I/JG26, zaś pilotem, który zasiadał za jego sterami, był najpewniej Uffz. Hans-Georg Becker. ${ }^{60}$ Drugie zadanie tego dnia - „Ramrod” 980 - dywizjony skrzydła wykonywały atakując oddzielne cele. 12 Mustangów 315 DM uzbrojonych w bomby wystartowało o godz. 9:05. Celem była stacja rozrządowa w rejonie Dreux (Eure-et-Loir). W drodze do celu klucz F/Lt Marciniaka w odległości ok. 24 km na południowy wschód od Rouen (Seine-Maritime) starł się z ugrupowaniem 10 myśliwców Bf $109 .{ }^{61} \mathrm{~W}$ rezultacie trwającej ok. 10 min. walki F/Lt Marciniak zgłosił jedno pewne i jedno prawdopodobne zestrzelenie, zaś po jednym pewnym zwycięstwie zameldowali F/O Maciej

55 TNA, CR, AIR-50-51-14, No. 129 Squadron, b.m., b.d., 2.

56 TNA, ORB, AIR-27-1701-11, No. 315 Squadron, b.m., b.d., 1.; AIR-27-1701-12, No. 315 Squadron, b.m., b.d., 1; IPiMS, 315 DM, LOT.A.V.53/50, Dziennik Działań Dywizjonu 1 IV 1944 r. - 4 IV 1945 r., b.m., b.d., b.p.

57 W Operations Record Books i Dzienniku Działań Dywizjonu zapisano, że start nastąpił o godz. 5:05, jednak w dokumentach 306 i 129 DM podano godzinę 6:05. TNA, ORB, AIR-27-1701-12, No. 315 Squadron, b.m., b.d., 1; AIR-27-1674-12, No. 306 Squadron, b.m., b.d., 1; AIR-27-934-66, No. 129 Squadron, b.m., b.d., 2; IPiMS, 315 DM, LOT.A.V.53/50, Dziennik Działań Dywizjonu 1 IV 1944 r. - 4 IV 1945 r., b.m., b.d., b.p.

58 TNA, ORB, AIR-27-1701-12, No. 315 Squadron, b.m., b.d., 1; IPiMS, 315 DM, LOT.A.V.53/50, Dziennik Działań Dywizjonu 1 IV 1944 r. - 4 IV 1945 r., b.m., b.d., b.p.; Thierry Arsicaud, „The Coordinates Translator," dostęp luty 20, 2021, http://www.echodelta.net/mbs/eng-translator.php.

59 TNA, CR, AIR-50-118-83, No. 315 Squadron, b.m., b.d., 1.

60 Grabowski, „D+1,” 1:30.

61 TNA, ORB, AIR-27-1701-12, No. 315 Squadron, b.m., b.d., 1-2; CR, AIR-50-125-62, No. 315 Squadron, b.m., b.d., 3-4; IPiMS, 315 DM, LOT.A.V.53/50, Dziennik Działań Dywizjonu 1 IV 1944 r. - 4 IV 1945 r., b.m., b.d., b.p. 
Kirste, F/Sgt Ryszard Idrian i F/Sgt Tadeusz Berka. Ofiarą Polaków prawdopodobnie padli piloci z III/JG1. ${ }^{62}$ Pozostała część dywizjonu pod dowództwem S/Ldr Horbaczewskiego wykonała m.in. bombardowanie stacji rozrządowej w rejonie Dreux. W trakcie ataku zarejestrowano cztery bezpośrednie trafienia w pociąg towarowy. Próbowano zniszczyć także torowiska, ale nie stwierdzono widocznych rezultatów. Piloci w Coolham lądowali pomiędzy 10:50 a 11:25. ${ }^{63}$ O godz. 14:10 nastąpił kolejny start. F/Lt Stefankiewicz i W/O Tamowicz wyruszyli na sprawdzenie pogody. Raport, z którym przylecieli o godz. 15:15, mówił o nie najlepszych, aczkolwiek umożliwiających wykonywanie zadań bojowych, warunkach atmosferycznych nad północną Francją. ${ }^{64}$ Dlatego też już 15 min. później, o godz. 15:30, 315 DM startował do kolejnego tego dnia „Ramrodu” 980. Zadanie miało polegać na zbombardowaniu $\mathrm{z}$ lotu nurkowego stacji rozrządowej zlokalizowanej ok. $3 \mathrm{~km}$ na południe od miejscowości Sées (Orne). Tym razem dywizjon prowadził osobiście dowódca 133 SM - W/Cdr Skalski. ${ }^{65}$ Osiem Mustangów uzbrojonych w bomby osłaniało pozostałe cztery samoloty w konfiguracji myśliwskiej. Piloci bez trudu zlokalizowali zaplanowany cel i zrzucili swój ładunek na skrzyżowanie torów kolejowych z drogą w zadanym rejonie. Zarejestrowano cztery bezpośrednie trafienia, po czym bez komplikacji powrócono do Coolham o godz. 17:50 ${ }^{66}$ Ostatni start dywizjonu tego dnia nastąpił o godz. 18:45. Celem była dwutorowa linia kolejowa przebiegająca ok. $6,5 \mathrm{~km}$ na południowy wschód od Argentan. ${ }^{67}$ Zadanie ponownie wykonywało osiem samolotów uzbrojonych w bomby, osłanianych przez cztery Mustangi w konfiguracji myśliwskiej. Prowadzącym w tym locie był F/Lt Marciniak.

62 TNA, CR, AIR-50-125-62, No. 315 Squadron, b.m., b.d., 3-4.; Grabowski, „D+1,” 1:31.

63 TNA, ORB, AIR-27-1701-12, No. 315 Squadron, b.m., b.d., 1-2; AIR-27-1701-11, No. 315 Squadron, b.m., b.d., 1; IPiMS, 315 DM, LOT.A.V.53/50, Dziennik Działań Dywizjonu 1 IV 1944 r. - 4 IV 1945 r., b.m., b.d., b.p.

64 TNA, ORB, AIR-27-1701-12, No. 315, b.m., b.d., 2; AIR-27-1701-11, No. 315 Squadron, b.m., b.d., 1; IPiMS, 315 DM, LOT.A.V.53/50, Dziennik Działań Dywizjonu 1 IV 1944 r. 4 IV 1945 r., b.m., b.d., b.p.

65 W/Cdr Skalski oraz W/Cdr Nowierski nie byli etatowymi pilotami 315 DM, choć ich nazwiska pojawiają się w ORB tej jednostki. W podsumowaniach dotyczących wysiłku bojowego dywizjonu uwzględniono wyłącznie etatowych pilotów.

66 TNA, ORB, AIR-27-1701-12, No. 315 Squadron, b.m., b.d., 2; AIR-27-1701-11, No. 315 Squadron, b.m., b.d., 1; IPiMS, 315 DM, LOT.A.V.53/50, Dziennik Działań Dywizjonu 1 IV 1944 r. - 4 IV 1945 r., b.m., b.d., b.p.; Arsicaud, „The Coordinates.”

67 Wpisy w Operations Record Books i Dzienniku Działań Dywizjonu wskazują, że cel ataku miał znajdować się w okolicach Écouché (Orne), ok. 6,5 km (4 mile) na południowy wschód od Argentan. Miejscowość Écouché położona jest jednak na południowy zachód od Argentan. Co więcej, pozostałe informacje z ORB w postaci kodowego identyfikatora lokalizacji, dowodzą, że cel znajdował się na południowy wschód od Argentan, gdzie również przebiegała linia kolejowa. Niespójność informacji w źródłach wynika prawdopodobnie z błędów popełnionych przy sporządzaniu wpisów. 
Bombardowanie celu przebiegło bez komplikacji, zarejestrowano dwa bezpośrednie trafienia, a lotnicy bezpiecznie lądowali w Coolham pomiędzy 20:30 a 20:40. ${ }^{68} 7$ czerwca F/Lt Marciniak został przeniesiony do $306 \mathrm{DM}$ na stanowisko dowódcy w miejsce S/Ldr Stanisława Łapki ${ }^{69}$, który tego samego dnia został zestrzelony i uznany za zaginionego. Miejsce F/Lt Marciniaka, jako dowódcy eskadry B, zajął F/O Michał Cwynar, który otrzymał funkcyjny stopień F/Lt. ${ }^{70}$ Drugi dzień inwazji był dla całego skrzydła najbardziej udany pod względem sukcesów odniesionych w walkach powietrznych. Pilotom trzech dywizjonów 133 SM przyznano zestrzelenie 17 samolotów przeciwnika na pewno, 3 prawdopodobnie oraz uszkodzenie 4. Był to najlepszy wynik spośród wszystkich jednostek alianckich uzyskany tego dnia. Dodatkowo w walce z polskimi lotnikami zginął niemiecki as myśliwski Hptm. Karl-Heinz Weber. 315 DM uzyskał pięć pewnych i jedno prawdopodobne zestrzelenie. ${ }^{71}$

8 czerwca dywizjon wykonał trzy loty na zadania „Ramrod” 982. Ataki na cele naziemne przeprowadzono $\mathrm{w}$ rejonie Tourouvre (Orne) oraz Vire (Calvados), celnie bombardując skrzyżowania dróg i linii kolejowych. ${ }^{72} \mathrm{Mi}-$ sje odbyły się bez komplikacji, z wyjątkiem ostatniej popołudniowej wyprawy, w trakcie której Mustang F/Lt Cwynara został trafiony przez artylerię przeciwlotniczą. Uszkodzenie instalacji chłodniczej samolotu uniemożliwiało lotnikowi powrót do bazy. Pilot zrzucił więc bomby w bezpiecznym miejscu i ok. godz. 16:00 wylądował awaryjnie ok. $10 \mathrm{~km}$ na północ od Caen (Calvados) po alianckiej stronie frontu, prawdopodobnie w okolicach Plumetot (Calvados). F/Lt Cwynar szybko trafil pod opiekę wojsk brytyjskich, a następnego dnia bezpiecznie wrócił do Coolham. Pozostałe trzy Mustangi bez przeszkód skutecznie zbombardowały skrzyżowanie dróg z torami kolejowymi w okolicach Boulon (Calvados), pomiędzy Caen i Falaise. ${ }^{73}$

68 TNA, ORB, AIR-27-1701-12, No. 315 Squadron, b.m., b.d., 2; AIR-27-1701-11, No. 315 Squadron, b.m., b.d., 1; IPiMS, 315 DM, LOT.A.V.53/50, Dziennik Działań Dywizjonu 1 IV 1944 r. - 4 IV 1945 r., b.m., b.d., b.p.; Arsicaud, „The Coordinates.”

69 S/Ldr Łapka powrócił do Wielkiej Brytanii 26 VIII 1944 r., zob. Matusiak, 306, 43.

70 TNA, ORB, AIR-27-1701-11, No. 315 Squadron, b.m., b.d., 1.

71 TNA, CR, AIR-50-118-66, No. 306 Squadron, b.m., b.d., 2; AIR-50-118-83, No. 315 Squadron, b.m., b.d.; AIR-50-125-62, No. 315 Squadron, b.m., b.d., 3-4; Grabowski, „D+1,” 1:32; Grabowski, „D+1,” 2:10; Shores i Thomas, 2nd, 1:142-143; Matusiak, 306, 63; Matusiak, Gretzyngier i Wiśniewski, 315, 112.

72 TNA, ORB, AIR-27-1701-12, No. 315 Squadron, b.m., b.d., 2; AIR-27-1701-11, No. 315 Squadron, b.m., b.d., 2; IPiMS, 315 DM, LOT.A.V.53/50, Dziennik Działań Dywizjonu 1 IV 1944 r. - 4 IV 1945 r., b.m., b.d., b.p.

73 TNA, ORB, AIR-27-1701-12, No. 315 Squadron, b.m., b.d., 3; AIR-27-1701-11, No. 315 Squadron, b.m., b.d., 2.; IPiMS, 315 DM, LOT.A.V.53/50, Dziennik Działań Dywizjonu 1 IV 1944 r. - 4 IV 1945 r., b.m., b.d., b.p.; LOT.A.V.53/3a, Kronika Dywizjonu 21 I 1941 r. - 13 VI 1944 r., b.m., b.d., b.p. 
W piątek 9 czerwca 1944 r. zła pogoda nie pozwoliła na wykonywanie lotów bojowych. ${ }^{74}$ Wznowiono je następnego dnia, który nie zaczął się jednak najlepiej. Do zadania „Ramrod” 986, mającego polegać na zbombardowaniu celu zlokalizowanego prawdopodobnie w rejonie Mortain (Manche), piloci dywizjonu wystartowali w dwóch czterosamolotowych kluczach. ${ }^{75}$ Po zrzuceniu bomb lotnicy poszukiwali kolejnych obiektów odpowiednich do ostrzelania przy użyciu broni pokładowej. ${ }^{76}$ Jak wspominał F/Sgt Bargiełowski, wspólnie z F/Lt Sworniowskim obrali za cel duży wojskowy namiot remontowy. Podczas ataku, w wyniku silnego ognia artylerii przeciwlotniczej, maszyna F/Lt Sworniowskiego została trafiona i uszkodzona. ${ }^{77}$ Lotnik próbował dolecieć do własnych linii, ale ok. godz. 8:00, w momencie kiedy jego Mustang FX960/PK-A zaczął się palić, wyskoczył ze spadochronem na północny wschód od Caen w rejonie miejscowości Escoville (Calvados). Po wylądowaniu prawdopodobnie najpierw próbował ukryć się w pobliskich zaroślach, a następnie przedostać do znajdujących się niedaleko alianckich linii. W rejonie tym znajdowało się wedle relacji F/Sgt Bargiełowskiego kilkanaście niemieckich czołgów. Jeden nich podjął pogoń za wycofującym się pilotem i ostrzelał go z karabinu maszynowego. W konsekwencji trafiony lotnik miał zginąć na miejscu. ${ }^{78}$ Alternatywna wersja wydarzeń została przedstawiona w „Dzienniku Działań Dywizjonu” oraz w „Operations Record Books" jednostki. F/Lt Sworniowski po wylądowaniu na spadochronie miał zostać przechwycony przez załogę niezidentyfikowanego czołgu i wzięty do niewoli. ${ }^{79}$ Istnieje też możliwość, że podjęty przez załogę czołgu lotnik został zastrzelony podczas próby ucieczki lub rozstrzelany. ${ }^{80}$ F/Lt Sworniowski był pierwszym poległym podczas inwazji pilotem $315 \mathrm{DM}$. W trakcie drugiego tego dnia zadania „Ramrod” $986 \mathrm{ok} .5 \mathrm{~km}$ na południowy zachód od Caen zauważono ok. 10 czołgów i 40 pojazdów, które następnie zbombardowano, nie rejestrując poważniejszych rezultatów. Podczas ostatniej,

74 TNA, ORB, AIR-27-1701-11, No. 315 Squadron, b.m., b.d., 2; IPiMS, 315 DM, LOT.A.V.53/50, Dziennik Działań Dywizjonu 1 IV 1944 r. - 4 IV 1945 r., b.m., b.d., b.p.

75 TNA, ORB, AIR-27-1701-12, No. 315 Squadron, b.m., b.d., 3; IPiMS, Dowództwo Polskich Sił Powietrznych, LOT.A.V.1/10/f, Wypadki lotnicze 1944, b.m., b.d., b.p.; 315 DM, LOT.A.V.53/50, Dziennik Działań Dywizjonu 1 IV 1944 r. - 4 IV 1945 r., b.m., b.d., b.p. Olgierd Cumft i Hubert Kazimierz Kujawa, Księga lotników polskich poległych zmarlych i zaginionych 1939-1946 (Warszawa: Wyd. Ministerstwa Obrony Narodowej, 1989), 497.

76 IPiMS, 315 DM, LOT.A.V.53/50, Dziennik Działań Dywizjonu 1 IV 1944 r. - 4 IV 1945 r., b.m., b.d., b.p.; Bargiełowski, Mustangiem, 102.

77 Bargiełowski, Mustangiem, 102.

78 Ibid.; Gretzyngier et al., Ku czci, 438.

79 IPiMS, 315 DM, LOT.A.V.53/3a, Kronika Dywizjonu 21 I 1941 r. - 13 VI 1944 r., b.m., b.d., b.p.

80 Grabowski, „D+1,” 1:30. 
wieczornej misji przeprowadzonej siłą całego dywizjonu, skutecznie zbombardowano cel znajdujący się ok. $2,5 \mathrm{~km}$ od Villers-Bocage (Calvados). ${ }^{81}$ Następnie w trakcie przelotu nad drogą Alençon (Orne) i Mamers (Sarthe) lotnicy zauważyli i zaatakowali przy użyciu broni pokładowej niemiecki konwój samochodowy, niszcząc dziewięć ciężarówek. ${ }^{82}$

10 czerwca do dywizjonu powrócił po kursie szkoleniowym F/O Bogdan Śmidowicz. Do jednostki przybyli także nowi piloci: F/Lt Jerzy Schmidt przydzielony do eskadry A oraz F/O Tadeusz Haczkiewicz przydzielony do eskadry B. Z kolei dywizjon opuścił F/Sgt Józef Zaleński. ${ }^{83}$

Następnego dnia ze względu na kiepskie warunki pogodowe nie wykonywano lotów bojowych. W tym samym czasie do jednostki dołączył F/O Gwido Świstuń, który został przydzielony do eskadry B. ${ }^{84}$

12 czerwca 1944 r. dywizjon rozpoczął od zadania „Armed Recce” ${ }^{\text {, }}$, polegającego na atakowaniu wybranych linii transportowych biegnących na południe od Caen. Osiem Mustangów oderwało się od pasa startowego w Coolham o godz. 6:20. Po dolocie w rejon zadania lotnicy zgodnie z planem zbombardowali wiadukt oraz linię kolejową w rejonie Saint-Pierre-du-Fresne (Calvados). Wiadukt prawdopodobnie został uszkodzony. Zaatakowano także torowisko w rejonie Amayé-sur-Orne (Calvados), rejestrując bezpośrednie trafienie. $\mathrm{W}$ trakcie zadania F/Lt Franciszek Wiza z powodu defektu silnika musiał lądować przymusowo na alianckim lotnisku polowym B11 w Longues-sur-Mer (Calvados) o godz. 7:30, skąd powrócił najpewniej następnego dnia ${ }^{86}$ Pozostali

${ }^{81}$ W dostępnych dokumentach źródłowych nie podano rodzaju celu.

82 TNA, ORB, AIR-27-1701-12, No. 315 Squadron, b.m., b.d., 3; AIR-27-1701-11, No. 315 Squadron, b.m., b.d., 2; IPiMS, 315 DM, LOT.A.V.53/50, Dziennik Działań Dywizjonu 1 IV 1944 r. - 4 IV 1945 r., b.m., b.d., b.p.

83 TNA, ORB, AIR-27-1701-11, No. 315 Squadron, b.m., b.d., 2; IPiMS, 315 DM, LOT.A.V.53/50, Dziennik Działań Dywizjonu 1 IV 1944 r. - 4 IV 1945 r., b.m., b.d., b.p.; LOT.A.V.53/3a, Kronika Dywizjonu 21 I 1941 r. - 13 VI 1944 r., b.m., b.d., b.p.

84 TNA, ORB, AIR-27-1701-11, No. 315 Squadron, b.m., b.d., 2; IPiMS, 315 DM, LOT.A.V.53/50, Dziennik Działań Dywizjonu 1 IV 1944 r. - 4 IV 1945 r., b.m., b.d., b.p.

85 Armed Recce (od ang. Armed Reconnaissance) - zbrojne rozpoznanie. Zadanie rozpoznawcze polegające na poszukiwaniu i atakowaniu celów w wyznaczonym rejonie. Rowley, D-Day, 113.

${ }^{86}$ W Kronice Dywizjonu zapisano, że F/Lt Wiza powrócił z Francji 13 czerwca. W Operations Record Books i Dzienniku Działań Dywizjonu można z kolei znaleźć rozbieżne informacje świadczące o udziale pilota w kolejnym locie bojowym już 14 czerwca, ale także o jego powrocie do jednostki dopiero w dn. 16 VI 1944 r. IPiMS, 315 DM, LOT.A.V.53/3a, Kronika Dywizjonu 21 I 1941 r. - 13 VI 1944 r.; LOT.A.V.53/50, Dziennik Działań Dywizjonu 1 IV 1944 r. - 4 IV 1945 r., b.m., b.d., b.p.; TNA, ORB, AIR-27-1701-12, No. 315 Squadron, b.m., b.d., 5; AIR-27-1701-11, No. 315 Squadron, b.m., b.d., 3; Arsicaud, „The Coordinates." 
lotnicy lądowali w bazie pomiędzy 8:25 a 8:45. ${ }^{87}$ Kolejny start tego dnia nastąpił o godz. 11:25. Zadanie miało ten sam charakter. Poszukiwano celów znajdujących się na trasie Caen-Lisieux-Falaise-Argentan-Mamers i Sées. Podczas dolotu do miejscowości Sées (Orne) czwórka polskich Mustangów napotkała maszyny wroga ${ }^{88}$ Polacy starli się najprawdopodobniej z myśliwcami z III./SG4, którzy tego dnia utracili cztery Fw 190 operujące w tym rejonie. ${ }^{89} \mathrm{~W}$ wyniku walki dwa pewne zestrzelenia zgłosił F/Sgt Bargiełowski, zaś po jednym pewnym zwycięstwie zameldowali S/Ldr Horbaczewski i F/O Kirste. ${ }^{90}$ Tego dnia wykonano jeszcze dwa loty bojowe, w trakcie których skutecznie zbombardowano podziemny schron w okolicach Mézidon-Canon (Calvados) oraz stację kolejową w Donville (Calvados) znajdującą się w pobliżu Saint-Pierre-sur-Dives (Calvados), a także zaatakowano i zniszczono przy użyciu broni pokładowej cysternę z benzyną oraz dwa inne pojazdy. ${ }^{91}$

13 czerwca 1944 r. piloci dywizjonu wystartowali do zadania „Ramrod” 995. Osiem Mustangów dywizjonu uzbrojonych w bomby, podzielonych na dwa czterosamolotowe klucze, miało zaatakować oddzielne cele. W trakcie zadania, ok. godz. 19:45 na trasie Flers-Domfront, dowodzący jednym z kluczy F/Lt Stefankiewicz zauważył pojedynczy samolot, który rozpoznał jako Fw 190. Polecił lecącym z nim pilotom zrzucić bomby i przygotować się do walki. Następnie skutecznie zaatakował, zmuszając przeciwnika do skoku ze spadochronem. ${ }^{92} \mathrm{~W}$ okolicach Les-Baux-de-Breteuil (Eure) rozpoznano i ostrzelano przy użyciu broni pokładowej bez widocznych rezultatów konwój ok. 10 pojazdów transportowych. Klucz niebiorący udziału $\mathrm{w}$ walce powietrznej wykonał bombardowanie bez większych przygód. Bomby zostały zrzucone na mosty na rzece Orne w rejonie Clécy (Calva-

87 TNA, ORB, AIR-27-1701-12, No. 315 Squadron, b.m., b.d., 4; AIR-27-1701-11, No. 315 Squadron, b.m., b.d., 2; IPiMS, 315 DM, LOT.A.V.53/50, Dziennik Działań Dywizjonu 1 IV 1944 r. - 4 IV 1945 r., b.m., b.d., b.p.

88 TNA, ORB, AIR-27-1701-12, No. 315 Squadron, b.m., b.d., 4; CR, AIR-50-125-69, No. 315 Squadron, b.m., b.d., 1-2; IPiMS, 315 DM, LOT.A.V.53/50, Dziennik Działań Dywizjonu 1 IV 1944 r. - 4 IV 1945 r., b.m., b.d., b.p.

89 Shores i Thomas, 2nd, 1:155.

90 TNA, ORB, AIR-27-1701-12, No. 315 Squadron, b.m., b.d., 4; AIR-27-1701-11, No. 315 Squadron, b.m., b.d., 2; CR, AIR-50-125-69, No. 315 Squadron, b.m., b.d., 1-2; IPiMS, 315 DM, LOT.A.V.53/50, Dziennik Działań Dywizjonu 1 IV 1944 r. - 4 IV 1945 r., b.m., b.d., b.p.; LOT.A.V.53/3a, Kronika Dywizjonu 21 I 1941 r. - 13 VI 1944 r., b.m., b.d., b.p.

91 TNA, ORB, AIR-27-1701-12, No. 315 Squadron, b.m., b.d., 4; AIR-27-1701-11, No. 315 Squadron, b.m., b.d., 2; IPiMS, 315 DM, LOT.A.V.53/50, Dziennik Działań Dywizjonu 1 IV 1944 r. - 4 IV 1945 r., b.m., b.d., b.p.; Arsicaud, „The Coordinates”.

92 TNA, ORB, AIR-27-1701-12, No. 315 Squadron, b.m., b.d., 4; AIR-27-1701-11, No. 315 Squadron, b.m., b.d., 2.; CR, AIR-50-125-30, No. 315 Squadron, b.m., b.d., 1; IPiMS, 315 DM, LOT.A.V.53/3a, Kronika Dywizjonu 21 I 1941 r. - 13 VI 1944 r., b.m., b.d., b.p.; Arsicaud, „The Coordinates”. 
dos). Potwierdzono dwa bezpośrednie trafienia w drogę dojazdową, tuż obok jednego z mostów. W okolicach Saint-Georges-de-Rouelley (Manche) podjęto atak przy użyciu broni pokładowej, ostrzeliwując zakamuflowane pojazdy. Nie zaobserwowano jednak widocznych rezultatów. Obydwa klucze wróciły do bazy bez przeszkód ok. godz. 21:25. ${ }^{93}$

14 czerwca 1944 r. pierwszy start nastąpił o godz. 7:30, kolejny o godz. 11:50. Podczas pierwszego zadania zbombardowano most kolejowy w okolicach Thury-Harcourt (Calvados) oraz most drogowy w tym samym rejonie, rejestrując trafienia jedynie $\mathrm{w}$ pobliżu celu. ${ }^{94} \mathrm{~W}$ trakcie drugiego zadania zbombardowano skoncentrowane na bocznicy kolejowej na zachodnich przedmieściach Paryża wagony, potwierdzając sześć bezpośrednich trafień. ${ }^{95}$

15 czerwca 1944 r. podczas pierwszego zadania dywizjon w sile ośmiu samolotów wykonał bombardowanie w rejonie Démouville (Calvados). 16 bomb zrzucono na cele na południowym skraju miejscowości Giberville (Calvados) oraz na las na południowy zachód od Démouville. ${ }^{96}$ W szystkie bomby spadły $\mathrm{w}$ wyznaczonym rejonie, ale nie zauważono widocznych rezultatów ataku. Komplet pilotów lądował w Coolham o godz. 13:05. ${ }^{97}$ Drugi start dywizjonu tego dnia nastąpił wieczorem o godz. 21:05. Osiem Mustangów ruszyło do zadania „Ramrod” 1003. Celem była stacja rozrządowa w rejonie Mézidon-Canon (Calvados) i skoncentrowanych na niej kilkaset wagonów. Po zrzuceniu bomb zarejestrowano 16 bezpośrednich trafień. W Coolham lądowano o godz. 22:30.98

W piątek 16 czerwca $1944 \mathrm{r}$. dywizjon w składzie ośmiu samolotów wykonał tylko jedno zadanie „Ramrod” 1008, startując o godz. 11:50.

93 TNA, ORB, AIR-27-1701-12, No. 315 Squadron, b.m., b.d., 4; AIR-27-1701-11, No. 315 Squadron, b.m., b.d., 2; IPiMS, 315 DM, LOT.A.V.53/50, Dziennik Działań Dywizjonu 1 IV 1944 r. - 4 IV 1945 r., b.m., b.d., b.p.; LOT.A.V.53/3a, Kronika Dywizjonu 21 I 1941 r. 13 VI 1944 r., b.m., b.d., b.p.; Arsicaud, „The Coordinates.”

94 TNA, ORB, AIR-27-1701-12, No. 315 Squadron, b.m., b.d., 4-5; AIR-27-1701-11, No. 315 Squadron, b.m., b.d., 3; IPiMS, 315 DM, LOT.A.V.53/50, Dziennik Działań Dywizjonu 1 IV 1944 r. - 4 IV 1945 r., b.m., b.d., b.p.

95 TNA, ORB, AIR-27-1701-12, No. 315 Squadron, b.m., b.d., 5; AIR-27-1701-11, No. 315 Squadron, b.m., b.d., 3; IPiMS, 315 DM, LOT.A.V.53/50, Dziennik Działań Dywizjonu 1 IV 1944 r. - 4 IV 1945 r., b.m., b.d., b.p; Arsicaud, „The Coordinates.”

$96 \mathrm{~W}$ dostępnych dokumentach nie podano rodzaju celów.

97 TNA, ORB, AIR-27-1701-12, No. 315 Squadron, b.m., b.d., 3; IPiMS, 315 DM, LOT.A.V.53/50, Dziennik Działań Dywizjonu 1 IV 1944 r. - 4 IV 1945 r., b.m., b.d., b.p.; Arsicaud, „The Coordinates.”

98 TNA, ORB, AIR-27-1701-12, No. 315 Squadron, b.m., b.d., 5; AIR-27-1701-11, No. 315 Squadron, b.m., b.d., 3; IPiMS, 315 DM, LOT.A.V.53/50, Dziennik Działań Dywizjonu 1 IV 1944 r. - 4 IV 1945 r., b.m., b.d., b.p.; Arsicaud, „The Coordinates.” 
W trakcie bombardowania mostu w rejonie Nonancourt (Eure) większość bomb spadła obok celu. Zarejestrowano jednak cztery bezpośrednie trafienia $\mathrm{w}$ drogę prowadzącą na przeprawę. O godz. 14:20 dywizjon był z powrotem na lotnisku Coolham. ${ }^{99}$

17 czerwca 1944 r., o godz. 5:00 dywizjon wystartował do zadania „Ramrod" 1012, którego celem miała być linia kolejowa w okolicach Damblainville (Calvados). S/Ldr Horbaczewski w trakcie dolotu do celu uznał, że pełne pokrycie chmur o bardzo niskiej podstawie nie pozwala na wykonanie bombardowania $\mathrm{z}$ bezpiecznej wysokości. Złe warunki atmosferyczne sprawiły, że „Dębliniacy” zawrócili do Anglii. Dowódca, prawdopodobnie nie chcąc marnować uzbrojenia, podjął decyzję o lądowaniu z podwieszonymi bombami na wyposażonym w asfaltowy pas lotnisku Ford. Około godz. 6:30 piloci z wielką ostrożnością posadzili samoloty na ziemi. Niecodzienna sytuacja sprawiła, że S/Ldr Horbaczewski musiał wyjaśnić swoją decyzję obecnemu na miejscu brytyjskiemu dowódcy. Sprawa ostatecznie zakończyła się jednak bez konsekwencji dyscyplinarnych, ${ }^{100}$ a piloci po rozbrojeniu samolotów z bomb jeszcze tego samego dnia wrócili do Coolham. ${ }^{101}$ Pogoda 17 czerwca długo się nie poprawiała. Kolejny start nastąpił o godz. 17:30. W efekcie przeprowadzonej misji skutecznie zbombardowano z lotu nurkowego infrastrukturę kolejową w okolicach Damblainville. Komplet samolotów lądował w Coolham o godz. 19:05. ${ }^{102}$

W niedzielę 18 czerwca 1944 r. 315 DM ruszał w powietrze o 17:30 w sile ośmiu samolotów. Wspólnie z pozostałymi dywizjonami $133 \mathrm{SM}$ wykonywano zadanie „Ramrod” 1015. Prowadzona przez W/Cdr Skalskiego formacja 23 samolotów miała zbombardować tunel kolejowy w Bernay (Eure), przerywając $\mathrm{w}$ ten sposób połączenie $\mathrm{z}$ Lisieux (Calvados). Złe warunki atmosferyczne sprawiły jednak, że tunelu nie udało się zlokalizować. W związku z tym w trakcie „zbrojnego rozpoznania” na trasie Lisieux-La Trinite De Reville \& Pont-l'Évêque-Queteville skrzydło atakowało

99 TNA, ORB, AIR-27-1701-12, No. 315 Squadron, b.m., b.d., 5; AIR-27-1701-11, No. 315 Squadron, b.m., b.d., 3; IPiMS, 315 DM, LOT.A.V.53/50, Dziennik Działań Dywizjonu 1 IV 1944 r. - 4 IV 1945 r., b.m., b.d., b.p.; Arsicaud, „The Coordinates.”

100 Należy zaznaczyć, że podobne lądowanie zaliczył wcześniej 306 DM. Wspominał o tym pilot tegoż dywizjonu F/Lt Lech Laszkiewicz. Hamlin i Davies, Coolham, 37. W obydwu przypadkach ryzykowne lądowania były prawdopodobnie powodowane niechęcią pilotów do zmarnowania bomb i obawą, że zostaną oskarżeni o trwonienie uzbrojenia.

101 TNA, ORB, AIR-27-1701-12, No. 315 Squadron, b.m., b.d., 6; IPiMS, 315 DM, LOT.A.V.53/50, Dziennik Działań Dywizjonu 1 IV 1944 r. - 4 IV 1945 r., b.m., b.d., b.p.; Kazimierz Kijak i Alan Scheckenbach, The Quiet One (Canberra: b.w., 2008), 201-202. Arsicaud, „The Coordinates.”

102 TNA, ORB, AIR-27-1701-12, No. 315 Squadron, b.m., b.d., 6; AIR-27-1701-11, b.m., b.d., 3; IPiMS, 315 DM, LOT.A.V.53/50, Dziennik Działań Dywizjonu 1 IV 1944 r. - 4 IV 1945 r., b.m., b.d., b.p.; Arsicaud, „The Coordinates.” 
napotkane cele. W rejonie Grangues (Calvados) bomby zrzucono na przebiegającą przez las drogę. Podobnie w okolicach Trinité-de-Réville (Eure), gdzie prócz drogi zaatakowano także linię kolejową. W obydwu przypadkach nie stwierdzono jednak widocznych efektów ataków. Z kolei w rejonie Lisieux celnie zrzucono bomby na ok. 100 wagonów skoncentrowanych na stacji rozrządowej. Następnie ruszono w drogę powrotną. Lądowanie w Coolham odbyło się pomiędzy godz. 19:38 a 19:50. ${ }^{103}$

W poniedziałek 19 czerwca 1944 r. przeprowadzono tylko jedno zadnie „Ramrod” 1021, do którego wystartowano o godz. 20:50. Podczas bombardowania zarejestrowano dwa bezpośrednie trafienia. ${ }^{104}$ Dywizjon bezpiecznie lądował w Coolham już po zmierzchu, o godz. 22:10. ${ }^{105}$

Następnego dnia 315 DM do pierwszej misji („Ramrod” 1022) startował wspólnie z pozostałymi dywizjonami skrzydła o godz. 5:55, a do kolejnej o 11:40. W trakcie drugiej misji, wykonywanej wspólnie z 306 DM, zaatakowano cele w okolicach Remaisnil (Somma). Pomimo silnej obrony przeciwlotniczej pilotom udało się uzyskać pięć bezpośrednich trafień, pozostałe bomby lokując bardzo blisko celów. W trakcie powrotu na stacji kolejowej w Rue (Somma) rozpoznano 40 zamaskowanych wagonów. Dywizjon lądował w Coolham o godz. 12:55. ${ }^{106}$ Następny start tego dnia miał miejsce o 15:05. Do zadania „Ramrod” 1022 ruszyło osiem samolotów. Misję wykonywano wspólnie z pozostałymi jednostkami skrzydła pod dowództwem W/Cdr Skalskiego. Trasa lotu wiodła w rejon Chartres-Nogent-le-Rotrou. Obiektem ataku była linia kolejowa w rejonie Nogent-le-Rotrou (Eure-et-Loir), na którą piloci dywizjonu zrzucili 16 bomb, spośród których 6 trafiło bezpośrednio $\mathrm{w}$ cel. $\mathrm{W}$ trakcie dalszego lotu ostrzelano i zniszczono też ciężarówkę wojskową. Lądowanie dywizjonu w Coolham odbyło się pomiędzy godz. 17:30 a 17:50. ${ }^{107}$ Ostatnie zadanie tego dnia wykonano w sile całego dywizjonu razem z resztą skrzydła. Start 12 Mustangów odbył się o godz. 19:10, 8 maszyn uzbrojono w bomby, zaś pozostałe 4 stanowiły osłonę

103 TNA, ORB, AIR-27-1701-12, No. 315 Squadron, b.m., b.d., 6; AIR-27-1701-11, No. 315 Squadron, b.m., b.d., 3; IPiMS, 315 DM, LOT.A.V.53/50, Dziennik Działań Dywizjonu 1 IV 1944 r. - 4 IV 1945 r., b.m., b.d., b.p.; Arsicaud, „The Coordinates.”

$104 \mathrm{~W}$ dostępnych dokumentach nie wskazano obiektu ani rejonu ataku.

105 TNA, ORB, AIR-27-1701-12, No. 315 Squadron, b.m., b.d., 6; AIR-27-1701-11, No. 315 Squadron, b.m., b.d., 3; IPiMS, 315 DM, LOT.A.V.53/50, Dziennik Działań Dywizjonu 1 IV 1944 r. - 4 IV 1945 r., b.m., b.d., b.p.; Arsicaud, „The Coordinates.”

106 TNA, ORB, AIR-27-1701-12, No. 315 Squadron, b.m., b.d., 6-7; AIR-27-1701-11, No. 315 Squadron, b.m., b.d., 3; IPiMS, 315 DM, LOT.A.V.53/50, Dziennik Działań Dywizjonu 1 IV 1944 r. - 4 IV 1945 r., b.m., b.d., b.p.

107 TNA, ORB, AIR-27-1701-12, No. 315 Squadron, b.m., b.d., 7; AIR-27-1701-11, No. 315 Squadron, b.m., b.d., 3; IPiMS, 315 DM, LOT.A.V.53/50, Dziennik Działań Dywizjonu 1 IV 1944 r. - 4 IV 1945 r., b.m., b.d., b.p. 
myśliwską. Celem zadania „Ramrod” 1022 była linia kolejowa w okolicach Rambouillet (Yvelines). Nie wszystkie samoloty jednak doleciały do celu. W drodze nad Francję F/Sgt Kępczyński zgłosił problemy z chłodzeniem silnika i w osłonie F/O Nowosielskiego wrócił do Anglii. Lotnicy lądowali na lotnisku Ford odpowiednio o godz. 19:50 i 20:00. Reszta dywizjonu wykonała zaplanowane zadanie. W okolicach Rambouillet piloci zrzucili bomby na skoncentrowane $\mathrm{w}$ tym rejonie wagony kolejowe, których liczbę szacowano na 200 bądź 300. Zarejestrowano 4 bezpośrednie trafienia, zaś pozostałe 12 bomb spadło bardzo blisko celu. ${ }^{108}$ Po wykonaniu zadania lotnicy wrócili do Coolham o godz. 21:10. Tego samego dnia do eskadry A został przydzielony przybyły do dywizjonu F/Lt Konrad Stembrowicz. ${ }^{109}$

21 czerwca 1944 r. o godz. 20:55 315 DM w sile 12 samolotów wystartował do zadania „Ramrod” 1027. 8 Mustangów uzbrojonych w bomby w osłonie 4 samolotów stanowiących osłonę myśliwską leciało nad Francję razem z 306 DM. Podczas zadania typu „Armed Recce” zbombardowano drogę $w$ rejonie Rambouillet oraz trafiono pięć pojazdów transportowych. Zaatakowano też węzeł kolejowy w rejonie L’Aigle (Orne), rejestrując dwa bezpośrednie trafienia. Przelatując w okolicach niemieckiego lotniska w Chartres Champhol (Eure-et-Loir), lotnicy dywizjonu napotkali intensywny i celny ogień ciężkiej artylerii przeciwlotniczej, ale mimo to udało im się zaobserwować na ziemi 14 samolotów rozpoznanych jako Heinkle He 111. Lądowanie w Coolham nastąpiło o godz. 22:45. ${ }^{110}$

22 czerwca 1944 r. 315 DM, wspólnie z innymi alianckimi jednostka$\mathrm{mi}$, wspierał z powietrza walczące $\mathrm{w}$ starciu o Cherbourg (Manche) wojska amerykańskie. Zadaniem dywizjonów 2nd TAF oraz amerykańskich jednostek lotniczych było izolowanie pola walki i bezpośrednie wsparcie wojsk lądowych. Około godz. 12:10 skrzydło wyleciało, aby zgodnie z rozkazem 2nd TAF OPS order No. 188 przeprowadzić ataki z lotu koszącego ${ }^{111}$ w rejonie na południe od Cherbourga. Atak miał być wykonany przy użyciu uzbrojenia pokładowego. ${ }^{12}$ Formację trzech dywizjonów prowadził dowódca skrzydła W/Cdr Skalski. W rezultacie skutecznie ostrzelano ok. 20 pojazdów znajdujących się w rejonie Octeville (Manche), meldując zniszczenie

\footnotetext{
108 TNA, ORB, AIR-27-1701-12, No. 315 Squadron, b.m., b.d., 7; Arsicaud, „The Coordinates.”

109 TNA, ORB, AIR-27-1701-12, No. 315 Squadron, b.m., b.d., 7; AIR-27-1701-11, No. 315 Squadron, b.m., b.d., 3; IPiMS, 315 DM, LOT.A.V.53/50, Dziennik Działań Dywizjonu 1 IV 1944 r. - 4 IV 1945 r., b.m., b.d., b.p.

110 TNA, ORB, AIR-27-1701-12, No. 315 Squadron, b.m., b.d., 7; AIR-27-1701-11, No. 315 Squadron, b.m., b.d., 4; IPiMS, 315 DM, LOT.A.V.53/50, Dziennik Działań Dywizjonu 1 IV 1944 r. - 4 IV 1945 r., b.m., b.d., b.p.

111 Lot koszący - lot wykonywany tuż nad ziemią.

112 TNA, ORB, AIR-27-1701-12, No. 315 Squadron, b.m., b.d., 7-8.
} 
jednego i uszkodzenie kilkunastu. W wyniku bardzo silnego ognia artylerii przeciwlotniczej zostały zestrzelone dwa samoloty $315 \mathrm{DM}$. F/Lt Stefankiewicz lecący Mustangiem FB398/PK-A ${ }^{113}$ ok. godz. 13:00 rozbił się ok. 4 km na południe od Cherbourga. Pierwotnie został uznany za zaginionego. Wrak samolotu wraz z pogrzebanym w jego szczątkach pilotem został odnaleziony i zidentyfikowany 30 czerwca 1944 r. przez żołnierzy 87 RAF Embarkation Unit. ${ }^{114}$ Więcej szczęścia miał drugi z trafionych tego dnia pilotów $315 \mathrm{DM}$ - W/O Tamowicz, który - chociaż lekko ranny - z powodzeniem wylądował uszkodzonym samolotem na bagnistej łące po alianckiej stronie frontu. Śledzący sytuację dowódca dywizjonu, S/Ldr Horbaczewski, zauważył zbudowane niedawno w pobliżu przez Amerykanów lotnisko polowe, a następnie posadził na nim swój samolot. ${ }^{115}$ Po krótkiej wymianie zdań pożyczył od żołnierzy jeepa i odnalazł Tamowicza niedaleko miejsca jego awaryjnego lądowania. Następnie pieszo dotarł do pilota, sprowadził go do samochodu i przywiózł na lotnisko. Obszerna kabina Mustanga pozwoliła wsiąść do samolotu obydwu lotnikom - Tamowicz na siedzeniu, a Horbaczewski na jego kolanach. W ten sposób po kilkunastu minutach piloci znaleźli się w Anglii. Tego samego dnia rozpoczęło się przebazowanie 133 SM na nowe lotnisko w Holmsley South. Był to element treningu przygotowujący cały personel do szybkiej zmiany lotnisk bazowania już na terenie kontynentu. Personel naziemny oraz sprzęt wysłano w drogę transportem lądowym. ${ }^{116}$

23 czerwca 1944 r. dywizjon wykonal jedno zadanie. Start z nowego lotniska nastąpił o godz. 9:15. Siedem Mustangów uzbrojonych w bomby wzniosło

113 Każdy z samolotów używanych w PSP, podobnie jak w RAF, posiadał indywidualny i niezmienny numer ewidencyjny przypisany do konkretnego egzemplarza. Litery kodowe jako oznaczenie taktyczne - zwykle składające się z dwóch członów: identyfikatora dywizjonu oraz identyfikatora samolotu, np. PK-A - wielokrotnie się zmieniały. Litery maszyny spisanej ze stanu zwykle malowano potem na innym egzemplarzu. Mogło się też zdarzyć, że konkretny samolot $\mathrm{w}$ dywizjonie $\mathrm{w}$ różnych okresach posiadał różne litery kodowe. Numer ewidencyjny jednak ciągle pozostawał ten sam i to on służy najczęściej do ustalenia losów konkretnego samolotu.

114 TNA, ORB, AIR-27-1701-12, No. 315 Squadron, b.m., b.d., 7; AIR-27-1701-11, No. 315 Squadron, b.m, b.d., 4; IPiMS, 315 DM, LOT.A.V.53/50, Dziennik Działań Dywizjonu 1 IV 1944 r. - 4 IV 1945 r., b.m., b.d., b.p.; Gretzyngier et al., Ku czci, 445.

115 Było to prawdopodobnie najbardziej wysunięte $\mathrm{w}$ tamtym momencie na północ czynne amerykańskie lotnisko polowe na półwyspie Cotentin w rejonie Beuzeville-au-Plain (Manche), znajdujące się ok. $30 \mathrm{~km}$ na południowy wschód od Cherbourga i oznaczone kryptonimem A-6. Z powodu braku dokładnych informacji dotyczących lokalizacji lądowania S/Ldr Horbaczewskiego nie można wykluczyć także innych lotnisk polowych budowanych przez Amerykanów w tym rejonie. David C. Johnson, U. S. Army Air Forces Continental Airfields (ETO) D-Day to V-E Day (Maxwell: Research Division USAF Historical Research Center, 1988), 13.

116 TNA, ORB, AIR-27-1701-12, No. 315 Squadron, b.m., b.d., 7-8; AIR-27-1701-11, No. 315 Squadron, b.m., b.d., 4 . 
się w powietrze w asyście czterech pełniących rolę osłony myśliwskiej. O 9:40, prawdopodobnie z powodu awarii samolotu, do bazy wrócił F/Sgt Czerwiński. Reszta jednostki kontynuowała misję „Armed Recce” na trasie: EvreauxVersalles-Chartres-Nogent-le-Rotrou-Briouze-Argentan-L'Aigle. 14 bomb zrzucono na linię kolejową na wschód od Ramboulliet. Zarejestrowano 7 trafień bezpośrednich oraz tyle samo w pobliżu celu. $\mathrm{Z}$ powrotem lądowano pomiędzy godziną 9:40 a 12:15. ${ }^{117}$ Tego samego dnia zginął były dowódca eskadry B 315 DM, F/Lt Marciniak, dowodzący w tym czasie 306 DM. ${ }^{118}$

24 czerwca 1944 r. pierwsze zadanie 315 DM wykonywał wspólnie z 306 DM. 12 Mustangów z czarnymi kogutami na burtach oderwało się od pasa lotniska Holmsley South o godz. 11:00. Osiem samolotów uzbrojono $\mathrm{w}$ bomby, zaś pozostałe cztery zapewniały osłonę myśliwską. Całą formację prowadził dowódca skrzydła - W/Cdr Skalski. Operacja polegała na zbombardowaniu celów w rejonie Tillières-sur-Avre (Eure), a następnie wymiataniu myśliwskim ${ }^{119} \mathrm{~W}$ rejonie ok. $16 \mathrm{~km}$ na południowy wschód od Évreux (Eure). Na wskazany cel zrzucono 16 bomb i prawdopodobnie trafiono stację kolejową. Po zakończeniu bombardowania dostrzeżono lecącą w kierunku północno-zachodnim nieprzyjacielską mieszaną formację złożoną z ok. 40 samolotów Bf 109 oraz Fw 190, należących do I i II Gruppe JG2 oraz III/JG3. ${ }^{120} \mathrm{~W}$ wyniku walki F/Lt Jerzy Polak zgłosił dwa pewne zestrzelenia Bf 109, natomiast F/Lt Jerzy Schmidt jedno pewne zestrzelenie Fw 190. O dwóch uszkodzonych Bf 109 zameldował F/O Kirste, zaś jednego uszkodzonego Bf 109 zgłosił F/Sgt Bargiełowski. ${ }^{121}$ Utracono jednak jednego z pilotów. Około godz. 12:00 w okolicach Tillières-sur-Avre na północny zachód od Dreux (Eure-et-Loir) zestrzelony został W/O Jan Adamiak, lecący Mustangiem FZ157/PK-Q. ${ }^{122}$ Pozostali lotnicy dywizjonu

\footnotetext{
117 TNA, ORB, AIR-27-1701-12, No. 315 Squadron, b.m., b.d., 8; AIR-27-1701-11, No. 315 Squadron, b.m., b.d., 4; IPiMS, 315 DM, LOT.A.V.53/50, Dziennik Działań Dywizjonu 1 IV 1944 r. - 4 IV 1945 r., b.m., b.d., b.p.

118 Gretzyngier et al., Ku czci, 447.

119 Sweep (wymiatanie) - typ zadania zazwyczaj wykonywanego przez ugrupowanie myśliwskie i polegającego na penetracji terenu przeciwnika w określonym rejonie, głównie w poszukiwaniu celów powietrznych. Wymiatanie, w zależności od okoliczności, mogło polegać również na atakowaniu celów innych niż powietrzne i być przeprowadzane niekoniecznie przez myśliwce. Odmianą tego samego zadnia, ale wykonywanego ściśle przeciwko wrogim samolotom, był „Fighter Sweep” (wymiatanie myśliwskie). Król, Polskie skrzydła, 47; Kalinowski, Lotnictwo Polskie, 101.

120 Shores i Thomas, 2nd, 1:179.

121 TNA, CR, AIR-50-436-64, No. 315 Squadron, b.m., b.d., 1-2.

122 Ibid., ORB, AIR-27-1701-12, No. 315 Squadron, b.m., b.d., 8; Gretzyngier et al., Ku czci, 447.
} 
bezpiecznie lądowali w Holmsley South pomiędzy 13:05 a 13:10. ${ }^{123}$ Kolejna misja tego dnia nie przyniosła spotkania $\mathrm{z}$ przeciwnikiem $\mathrm{w}$ powietrzu. Prowadzącym dywizjon był dowódca skrzydła W/Cdr Skalski. Start nastąpił o godz. 15:45. Zadanie typu „Armed Recce” przeprowadzono na trasie Alencon-Laval-Domfront. Zbombardowano infrastrukturę kolejową w postaci torowiska i kilku budynków. ${ }^{124}$ Cztery bomby spadły bezpośrednio na cele, zaś pozostałe nieznacznie chybiły. Dywizjon bezpiecznie lądował w Holmsley South o godz. 17:45. ${ }^{125}$

25 czerwca 1944 r. dla 315 DM rozpoczął się wczesnym rankiem. O godz. 5:00 F/O Wünsche oraz P/O Świstuń wystartowali na rozpoznanie pogody nad terenem nieprzyjaciela. Wrócili z raportem mówiącym o bardzo dobrych warunkach atmosferycznych w rozpoznanym rejonie, meldując także o widzianych ok. godz. 6:15 w powietrzu niemieckich samolotach. ${ }^{126}$ Kolejny start nastąpił o godz. 6:20, tym razem do zadania, w trakcie którego pozostałe dywizjony skrzydła w osłonie 315 DM zbombardowały linię kolejową pomiędzy Évreux i Conches-en-Ouche (Eure). Dywizjon wykonał zadanie bez przeszkód i lądował z powrotem o godz. 8:45. ${ }^{127}$ Ostatni start tego dnia nastąpił o godz. 13:45. Podobnie jak poprzednim razem, 315 DM lecący do tego zadania w sile dziewięciu samolotów, miał stanowić osłonę myśliwską dla pozostałych, uzbrojonych w bomby Mustangów skrzydła. Piloci wykonali zadanie, zrzucając swój ładunek na wiadukty kolejowe pomiędzy Briouze (Orne) a La Ferté-Macé (Orne). Osłona myśliwska nie napotkała samolotów przeciwnika. Tego dnia rozpoczęły się też kolejne przenosiny skrzydła, tym razem na dobrze znane lotnisko Ford. Dywizjon lądował więc już w nowej bazie pomiędzy godz. 15:45 a 16:15. Tego samego dnia z 306 DM do 315 DM przeszedł F/Lt Henryk Pietrzak, który objął dowództwo eskadry A, w miejsce poległego F/Lt Stefankiewicza. ${ }^{128}$

123 TNA, ORB, AIR-27-1701-12, No. 315 Squadron, b.m., b.d., 8; AIR-27-1701-11, No. 315 Squadron, b.m., b.d., 4; IPiMS, 315 DM, LOT.A.V.53/50, Dziennik Działań Dywizjonu 1 IV 1944 r. - 4 IV 1945 r., b.m., b.d., b.p.

124 W dostępnych dokumentach źródłowych nie podano dokładnej lokalizacji celu.

125 TNA, ORB, AIR-27-1701-12, No. 315 Squadron, b.m., b.d., 8; AIR-27-1701-11, No. 315 Squadron, b.m., b.d., 4; IPiMS, 315 DM, LOT.A.V.53/50, Dziennik Działań Dywizjonu 1 IV 1944 r. - 4 IV 1945 r., b.m., b.d., b.p.

126 TNA, ORB, AIR-27-1701-12, No. 315 Squadron, b.m., b.d., 8; AIR-27-1701-11, No. 315 Squadron, b.m., b.d., 4 .

127 TNA, ORB, AIR-27-1701-12, No. 315 Squadron, b.m., b.d., 9; AIR-27-1701-11, No. 315 Squadron, b.m., b.d., 4; IPiMS, 315 DM, LOT.A.V.53/50, Dziennik Działań Dywizjonu 1 IV 1944 r. - 4 IV 1945 r., b.m., b.d., b.p.

128 TNA, ORB, AIR-27-1701-12, No. 315 Squadron, b.m., b.d., 9; AIR-27-1701-11, No. 315 Squadron, b.m., b.d., 4; IPiMS, 315 DM, LOT.A.V.53/50, Dziennik Działań Dywizjonu 1 IV 1944 r. - 4 IV 1945 r., b.m., b.d., b.p. 
26 czerwca 1944 r. całe 133 SM zostało przebazowane na stację RAF Ford. Personel naziemny i sprzęt przetransportowano drogą lądową. Samoloty w większości już poprzedniego dnia odleciały na nowe miejsce stacjonowania. ${ }^{129}$

Następnego dnia $315 \mathrm{DM}$ do pierwszego zadania startował o godz. 12:05. Misję wykonywano w pełnej sile 12 samolotów wspólnie z $306 \mathrm{DM}$, który ruszył w powietrze kilkanaście minut później. Na czele ponownie leciał W/Cdr Skalski. Oprócz dwóch pilotów, którzy z powodu problemów technicznych musieli wcześniej wrócić do bazy, reszta wykonała zadanie bez przeszkód. Zbombardowano węzeł kolejowy na południowy wschód od Flers (Orne). ${ }^{130}$ Zarejestrowano cztery bezpośrednie trafienia - trzy w pó1nocnej i jedno w południowej części celu. Następnie wykonano wymiatanie myśliwskie $\mathrm{w}$ rejonie Laval (Mayenne), po czym powrócono na lotnisko. Lądowanie odbyło się pomiędzy 14:10 a 14:40. ${ }^{131}$ O godz. 20:40 dywizjon wystartował do ostatniego zadania tego dnia, razem z 306 DM. Przeprowadzono wymiatanie myśliwskie w rejonie Flers-Argentan-Évreux, podczas którego nie napotkano jednak samolotów przeciwnika. Dywizjon lądował o godz. $22: 30 .^{132}$

28 czerwca 1944 r. nie wykonywano lotów bojowych, ale jako uzupełnienie do dywizjonu przybył P/O Aleksander Judek, który został przydzielony do eskadry A. ${ }^{133}$

Kolejny dzień rozpoczęto od zadania przeprowadzanego wspólnie z dywizjonami myśliwskimi 129 i 306. Start z lotniska Ford nastąpił o godz. 7:40. Celem misji był węzeł kolejowy w rejonie Le Château-d'Almenêches (Orne). Zrzucono nań osiem bomb i zarejestrowano dwa bezpośrednie oraz kilka trafień $\mathrm{w}$ pobliżu celu. Dywizjon bezpiecznie lądował z powrotem o godz. 9:25. ${ }^{134} \mathrm{~W}$ drugim zadaniu tego dnia jednostka wzięła udział w sile 11 samolotów. Uzbrojone w bomby Mustangi 315 DM startowały o godz. 15:30. Misję wykonywano wspólnie z pozostałymi dywizjonami skrzydła.

\footnotetext{
129 TNA, ORB, AIR-27-1701-11, No. 315 Squadron, b.m., b.d., 4; IPiMS, 315 DM, LOT.A.V.53/50, Dziennik Działań Dywizjonu 1 IV 1944 r. - 4 IV 1945 r., b.m., b.d., b.p.

130 TNA, ORB, AIR-27-1701-12, No. 315 Squadron, b.m., b.d., 9.

131 TNA, ORB, AIR-27-1701-12, No. 315 Squadron, b.m., b.d., 9; AIR-27-1701-11, No. 315 Squadron, b.m., b.d., 4; IPiMS, 315 DM, LOT.A.V.53/50, Dziennik Działań Dywizjonu 1 IV 1944 r. - 4 IV 1945 r., b.m., b.d., b.p.; Arsicaud, „The Coordinates.”

132 TNA, ORB, AIR-27-1701-12, No. 315 Squadron, b.m., b.d., 9; AIR-27-1701-11, No. 315 Squadron, b.m., b.d., 5; IPiMS, 315 DM, LOT.A.V.53/50, Dziennik Działań Dywizjonu 1 IV 1944 r. - 4 IV 1945 r., b.m., b.d., b.p.

133 TNA, ORB, AIR-27-1701-11, No. 315 Squadron, b.m., b.d., 5.

134 Ibid.; AIR-27-1701-12, No. 315 Squadron, b.m., b.d., 10; IPiMS, 315 DM, LOT.A.V.53/50, Dziennik Działań Dywizjonu 1 IV 1944 r. - 4 IV 1945 r., b.m., b.d., b.p.
} 
Samoloty w konfiguracji bombowej skutecznie zaatakowały skrzyżowanie dróg i torów kolejowych. ${ }^{135}$ Potwierdzono 20 bezpośrednich trafień oraz 2 trafienia pośrednie. Formacja lądowała $\mathrm{z}$ powrotem o godz. 17:45. ${ }^{136}$

30 czerwca o godz. 18:20 siedmiu pilotów dywizjonu, jako osłona myśliwska, wystartowało do jedynego zadania tego dnia wraz z resztą skrzydła. Uzbrojone $\mathrm{w}$ bomby samoloty tym razem nie trafiły żadnego $\mathrm{z}$ założonych celów, którymi były mosty zlokalizowane prawdopodobnie na południe od Caen. Potwierdzono jedynie kilka pośrednich trafień. Następnie całe ugrupowanie wykonało wymiatanie w rejonie Falaise-Argentan, jednak nie napotkano tam samolotów przeciwnika. Zaobserwowano wyłącznie ruch pojedynczych pojazdów transportowych przemieszczających się w kierunku północnym. Jeden $\mathrm{z}$ nich zniszczono na drodze $\mathrm{z}$ Falaise do Pont-d'Ouilly (Calvados). Po wykonanym zadaniu piloci powrócili do bazy o godz. 20:00, wieńcząc tym samym czerwcowy okres służby. ${ }^{137}$

315 DM od 6 do 30 czerwca 1944 r. wziął udział w 45 wyprawach, wykonując 363 samolotozadania w łącznym czasie 754 godzin i 10 minut. ${ }^{138}$ Zrzucono ok. 500 bomb o łącznym wagomiarze ok. $113395 \mathrm{~kg} .{ }^{139}$ Uzyskano 13 pewnych zestrzeleń, 1 zestrzelenie prawdopodobne oraz 3 uszkodzenia. ${ }^{140}$

135 W dostępnych dokumentach źródłowych nie podano dokładnej lokalizacji celu.

136 TNA, ORB, AIR-27-1701-12, No. 315 Squadron, b.m., b.d., 10; AIR-27-1701-11, No. 315 Squadron, b.m., b.d., 5; IPiMS, 315 DM, LOT.A.V.53/50, Dziennik Działań Dywizjonu 1 IV 1944 r. - 4 IV 1945 r., b.m., b.d., b.p.; Arsicaud, „The Coordinates.”

137 TNA, ORB, AIR-27-1701-12, No. 315 Squadron, b.m., b.d., 10; AIR-27-1701-11, No. 315 Squadron, b.m., b.d., 5; IPiMS, 315 DM, LOT.A.V.53/50, Dziennik Działań Dywizjonu 1 IV 1944 r. - 4 IV 1945 r., b.m., b.d., b.p.; Arsicaud, „The Coordinates.”

138 W celu podsumowania wysiłku bojowego 315 DM od 6 do 30 VI 1944 r. od liczb podanych w oficjalnym sprawozdaniu miesięcznym za czerwiec 1944 r., odjęto 16 samolotozadań wykonanych 3 VI 1944 r. Obliczenia dotyczące czasu lotu poczyniono na podstawie sprawozdania miesięcznego, ORB oraz wybranych książek lotów pilotów. Z powodu braku dostępu do wszystkich indywidualnych książek lotów łączny czas lotu został podany w przybliżeniu i może różnić się od rzeczywistego o kilka godzin.

139 Liczbę oraz wagomiar zrzuconych bomb podano szacunkowo na podstawie informacji zawartych w ORB, Dzienniku Działań Dywizjonu oraz sprawozdaniu miesięcznym. Przy obliczaniu liczby i ciężaru zrzuconych bomb wzięto pod uwagę najczęściej wykorzystywane bomby o wadze 500 funtów $(226,79 \mathrm{~kg})$.

140 IPiMS, 315 DM, LOT.A.V.53/6, Sprawozdanie z pracy Dyonu za miesiąc czerwiec 1944 r., RAF Station Ford, 2 VII 1944 r., b.p.; LOT.A.V.53/50, Dziennik Działań Dywizjonu 1 IV 1944 r. - 4 IV 1945 r., b.m., b.d., b.p.; TNA, ORB, AIR-27-1701-12, No. 315 Squadron, b.m., b.d, 1-10; Pilot's Flying Log Book: Jakub Bargiełowski; Pilot's Flying Log Book: Bożydar Nowosielski; Pilot's Flying Log Book: Michał Cwynar; Pilot's Flying Log Book: Kazimierz Kijak; Pilot's Flying Log Book: Henryk Pietrzak; Pilot's Flying Log Book: Tadeusz Słoń; Pilot's Flying Log Book: Tadeusz Tamowicz; Pilot's Flying Log Book: Kazimierz Wünsche. Książki pilotów w zbiorach autora. 


\section{Lipiec 1944}

Do realizacji zadań bojowych powrócono w poniedziałek 3 lipca. Całe skrzydło w sile 36 samolotów startowało o godz. 19:20 do zadania polegającego na bombardowaniu i zbrojnym rozpoznaniu. Dziewięć samolotów dywizjonu uzbrojono w bomby, pozostałe zaś miały stanowić osłonę myśliwską. Nad Francją pogoda nie była najlepsza. Zamiast pierwotnie zakładanego celu zaatakowano linię kolejową na północ od Argentan, rejestrując cztery bezpośrednie trafienia $\mathrm{w}$ tory oraz nasyp kolejowy. Następnie lotnicy przeszli do rozpoznania na trasie Lisieux-Évreux-Dreux-L'Aigle. Po drodze jednak nie napotkano nieprzyjaciela. ${ }^{141}$

4 lipca 1944 r. dywizjon, wspólnie z całym skrzydłem, znowu wykonywał zadanie polegające na bombardowaniu i zbrojnym rozpoznaniu. Ponownie osiem dęblińskich Mustangów uzbrojono w bomby, zaś pozostałe cztery miały stanowić dla nich osłonę myśliwską. Start nastąpił o godz. 9:45. Celem operacji była linia kolejowa L'Aigle-Sainte-Gauburge-Ste-Colombe. 16 bomb zostało zrzuconych na węzeł kolejowy w rejonie Le Châteaud'Almenêches (Orne). Zarejestrowano trzy bezpośrednie trafienia, które uszkodziły tory oraz kilka trafień pośrednich, w wyniku których uszkodzone zostały nasypy kolejowe. Następnie ostrzelano przy użyciu broni pokładowej trzy pojazdy transportowe i holowane stanowisko karabinu maszynowego, potwierdzając jego zniszczenie. ${ }^{142}$ Po południu tego dnia, o godz. 16:30, F/Lt Schmidt oraz F/Sgt Będkowski wystartowali do pierwszego patrolu na przechwycenie „latającej bomby” V1. Wkrótce alarm został jednak odwołany, a piloci wrócili do bazy o godz. 17:10. Podczas ostatniego wylotu bojowego tego dnia piloci dywizjonu wykonali wymiatanie $\mathrm{w}$ rejonie Évreux. Start nastąpił o godz. 20:05. ${ }^{143}$ Krótko po nim problemy z silnikiem zgłosił F/Lt Schmidt i wkrótce musiał wrócić na lotnisko, gdzie bezpiecznie wylądował o godz. 20:35. Reszta dywizjonu wykonała misję zgodnie z planem. Nie napotkano jednak samolotów wroga, nie dostrzeżono też żadnych dobrych do zaatakowania celów. ${ }^{144}$

141 TNA, ORB, AIR-27-1701-14, No. 315 Squadron, b.m., b.d., 1; AIR-27-1701-13, No. 315 Squadron, b.m., b.d., 1; IPiMS, 315 DM, LOT.A.V.53/50, Dziennik Działań Dywizjonu 1 IV 1944 r. - 4 IV 1945 r., b.m., b.d., b.p.; Arsicaud, „The Coordinates.”

142 TNA, ORB, AIR-27-1701-14, No. 315 Squadron, b.m., b.d., 1; AIR-27-1701-13, No. 315 Squadron, b.m., b.d., 1; IPiMS, 315 DM, LOT.A.V.53/50, Dziennik Działań Dywizjonu 1 IV 1944 r. - 4 IV 1945 r., b.m., b.d., b.p.; Arsicaud, „The Coordinates.”

143 TNA, ORB, AIR-27-1701-14, No. 315 Squadron, b.m., b.d., 1; IPiMS, 315 DM, LOT.A.V.53/50, Dziennik Działań Dywizjonu 1 IV 1944 r. - 4 IV 1945 r., b.m., b.d., b.p.

144 TNA, ORB, AIR-27-1701-14, No. 315 Squadron, b.m., b.d., 1; AIR-27-1701-13, No. 315 Squadron, b.m., b.d., 1; IPiMS, 315 DM, LOT.A.V.53/50, Dziennik Działań Dywizjonu 1 IV 1944 r. - 4 IV 1945 r., b.m., b.d., b.p. 
5 lipca $315 \mathrm{DM}$, w sile 12 samolotów, wykonał jedno zadanie razem z 306 DM. Osiem Mustangów jednostki uzbrojonych w bomby w osłonie czterech samolotów w konfiguracji myśliwskiej, wystartowało o godz. 11:15. Zadanie typu „Armed Recce” przeprowadzono na trasie linii kolejowej Évreux-L’Aigle-Dreux-Évreux. Na północny zachód od Conches-en-Ouche (Eure) zrzucono bomby na węzeł kolejowy i ok. 50 wagonów stojących na bocznicach, rejestrując cztery bezpośrednie oraz kilka trafień pośrednich. ${ }^{145}$

6 lipca dywizjon wykonał jedną misję bombardowania $\mathrm{z}$ lotu nurkowego w rejonie Verneuil d'Avre et d'Iton (Eure). Zadanie przeprowadzano wspólnie ze 129 DM RAF. Podobnie jak poprzedniego dnia osiem samolotów dywizjonu uzbrojono $\mathrm{w}$ bomby, zaś pozostałe cztery miały zapewnić im osłonę myśliwską. Start nastąpił wieczorem o godz. 20:40. W rejonie Verneuil d'Avre et d'Iton zbombardowano zgrupowanie ok. 160 ciężarówek, rejestrując osiem bezpośrednich trafień. Wykonano także zbrojne rozpoznanie na trasie Brionne-Conches-en-Ouche-Le Neubourg. ${ }^{146}$ Zaatakowano przy użyciu broni pokładowej rozpoznane pozycje lekkiej artylerii przeciwlotniczej. Dywizjon lądował z powrotem pomiędzy $22: 20$ a $22: 40 .{ }^{147}$

7 lipca 1944 r. pierwszy start nastąpił o godz. 8:55. Zadanie miało zostać wykonane wspólnie ze 129 DM RAF. Ponownie osiem Mustangów 315 DM uzbrojonych $\mathrm{w}$ bomby leciało razem $\mathrm{z}$ czterema myśliwcami stanowiącymi osłonę. W rejonach Rouen (Seine-Maritime), Elbeuf (Seine-Maritime) i na wschód od Elbeuf, zbombardowano i ostrzelano przy użyciu broni pokładowej stanowiska ciężkich i średnich dział przeciwlotniczych. Zniszczono także magazyn amunicji w okolicach La Bonneville-sur-Iton (Eure) oraz jeden pojazd transportowy. Lot nie trwał tyle czasu, ile pierwotnie zakładano, ponieważ stale pogarszała się pogoda, w związku z czym zrezygnowano $\mathrm{z}$ dalszego rozpoznania. ${ }^{148} \mathrm{Na}$ lepsze warunki czekano do wieczora. Drugi start nastąpił o godz. 20:25. Tym razem dywizjon leciał wspólnie z całym skrzydłem w sile 36 samolotów. Podobnie jak ostatnio osiem Mustangów jednostki uzbrojono w bomby, zaś pozostałe cztery miały stanowić dla nich

145 TNA, ORB, AIR-27-1701-14, No. 315 Squadron, b.m., b.d., 1-2; AIR-27-1701-13, No. 315 Squadron, b.m., b.d., 1; IPiMS, 315 DM, LOT.A.V.53/50, Dziennik Działań Dywizjonu 1 IV 1944 r. - 4 IV 1945 r., b.m., b.d., b.p; Arsicaud, „The Coordinates.”

146 TNA, ORB, AIR-27-1701-14, No. 315 Squadron, b.m., b.d., 1-2; AIR-27-1701-13, No. 315 Squadron, b.m., b.d., 1; Arsicaud, „The Coordinates.”

147 TNA, ORB, AIR-27-1701-14, No. 315 Squadron, b.m., b.d., 2; AIR-27-1701-13, No. 315 Squadron, b.m., b.d., 1; IPiMS, 315 DM, LOT.A.V.53/50, Dziennik Działań Dywizjonu 1 IV 1944 r. - 4 IV 1945 r., b.m., b.d., b.p.; Arsicaud, „The Coordinates.”

148 TNA, ORB, AIR-27-1701-14, No. 315 Squadron, b.m., b.d., 2; AIR-27-1701-13, No. 315 Squadron, b.m., b.d., 1; IPiMS, 315 DM, LOT.A.V.53/50, Dziennik Działań Dywizjonu 1 IV 1944 r. - 4 IV 1945 r., b.m., b.d., b.p.; Arsicaud, „The Coordinates.” 
osłonę myśliwską. ${ }^{149}$ Operacja polegała na zlokalizowaniu i zaatakowaniu sił niemieckich zamaskowanych w lesie w rejonie La Baux-de-Breteuil (Eure). W wyznaczonym rejonie zaobserwowano jedynie ciężarówkę wojskową na polanie leśnej. Bomby zrzucono więc na mosty na rzece Risle w rejonie Nassandres (Eure). Większość z nich jednak chybiła $\mathrm{z}$ powodu silnego wiatru. ${ }^{150}$ Zarejestrowano cztery bezpośrednie trafienia w zachodnią drogę dojazdową do mostu i kilka trafień w pobliżu celu. Lądowanie nastąpiło o godz. 22:20. ${ }^{151}$ Było to ostatnie zadanie, jakie 315 DM przeprowadził podczas operacji „Overlord”. W ciągu kolejnych dwóch dni nie wykonywano lotów operacyjnych. 9 lipca 1944 r. odbył się jedynie przelot 16 samolotów na nowe lotnisko stacjonowania Brenzett ALG koło Ashford w hrabstwie Kent. 10 lipca przeniosła się tam reszta personelu $133 \mathrm{SM}^{152}$ Włączona do struktury Powietrznej Obrony Wielkiej Brytanii jednostka miała zająć się teraz zwalczaniem „latających bomb” V1. ${ }^{153}$

\section{Podsumowanie}

315 DM w okresie od 6 czerwca do 7 lipca 1944 r. wziął udział w 52 wyprawach, wykonując 445 samolotozadań w łącznym czasie 917 godzin i 45 minut. ${ }^{154}$ Zrzucono ok. 600 bomb o łącznym wagomiarze ok. $136074 \mathrm{~kg} .{ }^{155}$ W pierwszych dniach lipca wynik dotyczący zestrzeleń wpisanych na konto dywizjonu nie zmienił się. Łącznie $\mathrm{w}$ okresie bezpośredniego udziału w operacji „Overlord” uzyskano 13 pewnych zestrzeleń, 1 zestrzelenie

149 TNA, ORB, AIR-27-1701-14, No. 315 Squadron, b.m., b.d., 2; AIR-27-1701-13, No. 315 Squadron, b.m., b.d., 1.

150 Ibid. AIR-27-1701-14, No. 315 Squadron, b.m., b.d., 2; AIR-27-1701-13, No. 315 Squadron, b.m., b.d., 1; Arsicaud, „The Coordinates.”

151 TNA, ORB, AIR-27-1701-14, No. 315 Squadron, b.m., b.d., 2; AIR-27-1701-13, No. 315 Squadron, b.m., b.d., 1; IPiMS, 315 DM, LOT.A.V.53/50, Dziennik Działań Dywizjonu 1 IV 1944 r. - 4 IV 1945 r., b.m., b.d., b.p.

152 TNA, ORB, AIR-27-1701-13, No. 315 Squadron, b.m., b.d., 1; IPiMS, 315 DM, LOT.A.V.53/50, Dziennik Działań Dywizjonu 1 IV 1944 r. - 4 IV 1945 r., b.m., b.d., b.p.

153 TNA, ORB, AIR-27-1701-14, No. 315 Squadron, b.m., b.d., 3; AIR-27-1701-13, No. 315 Squadron, b.m., b.d., 1.

154 W celu podsumowania wysiłku bojowego 315 DM od 6 VI do 7 VII 1944 r. od liczb podanych w oficjalnych sprawozdaniach miesięcznych z czerwca i lipca 1944 r. odjęto 16 samolotozadań wykonanych 3 VI 1944 r. oraz 19 samolotozadań wykonanych po 7 VII 1944 r. Obliczenia dotyczące czasu lotu poczyniono jak w przypadku wyliczeń czerwcowych, zob. przyp. 138.

155 Liczbę oraz wagomiar zrzuconych bomb podano tak samo jak w przypadku wyliczeń dla czerwca, zob. przyp. 139. 
prawdopodobne oraz 3 uszkodzenia. ${ }^{156} \mathrm{~W}$ omawianym czasie najwięcej zwycięstw wpisali na swoje konto F/O Kirste - 2 zestrzelenia pewne i 2 uszkodzenia, F/Sgt Bargiełowski - 2 zestrzelenia pewne i 1 uszkodzenie, F/Lt Polak - 2 zestrzelenia pewne. Pozostali lotnicy dywizjonu, którym zaliczono w tym okresie zwycięstwa powietrzne, to: F/Lt Marciniak - 1 zestrzelenie pewne i 1 prawdopodobne, F/Sgt Berka - 1 zestrzelenie pewne, S/Ldr Horbaczewski - 1 zestrzelenie pewne, F/Sgt Idrian - 1 zestrzelenie pewne, F/Lt Stefankiewicz - 1 zestrzelenie pewne, F/Lt Sworniowski - 1 zestrzelenie pewne i F/Lt Schmidt - 1 zestrzelenie pewne. W tym samym okresie w trakcie walk poległo 3 pilotów 315 DM: F/Lt Sworniowski, F/Lt Stefankiewicz i W/O Adamiak. ${ }^{157}$

Wysiłek 2nd TAF, a w tym i 133 SM wraz z wchodzącym w jego skład 315 DM, w znaczący sposób przyczynił się do powodzenia operacji „Overlord”. Ataki na cele naziemne, przeprowadzone przez myśliwce przy użyciu bomb czy uzbrojenia pokładowego, miały istotny wpływ na sytuację niemieckich oddziałów. Stała obecność samolotów nad terenem wroga zmuszała Niemców do ograniczenia swojej aktywności, przede wszystkim do godzin nocnych. Przemieszczanie wojsk czy transportów po drogach $\mathrm{w}$ ciągu dnia $\mathrm{w}$ przytłaczającym stopniu narażało je na ataki z powietrza i straty, a co za tym idzie niemożność dokonania uzupełnień dla oddziałów na pierwszej linii frontu. To swoiste wydłużenie niemieckich linii zaopatrzenia było przede wszystkim zasługą ciągle obecnych nad Francją alianckich samolotów i w znaczący sposób przyczyniło się do sukcesu. Pomimo stosunkowo krótkiego udziału w operacji „Overlord”, 315 DM pozytywnie zaznaczył swoją obecność na francuskim niebie i pomógł przechylić szalę zwycięstwa na froncie zachodnim.

Autor składa serdeczne podziękowania za udostępnione materiały oraz pomoc merytoryczną panom Wojtkowi Matusiakowi, dr. Grzegorzowi Śliżewskiemu, Franciszkowi Grabowskiemu, Alanowi Scheckenbachowi i Nikolasowi Efreme.

156 IPiMS, 315 DM, LOT.A.V.53/6, Sprawozdanie z pracy Dyonu za miesiąc czerwiec 1944 r., RAF Station Ford, 2 VII 1944 r., b.p.; LOT.A.V.53/6, Sprawozdanie z pracy Dyonu za miesiąc lipiec 1944 r., b.m., 4 VIII 1944 r., b.p.; LOT.A.V.53/50, Dziennik Działań Dywizjonu 1 IV 1944 r. - 4 IV 1945 r., b.m., b.d., b.p.; TNA, ORB, AIR-27-1701-12, No. 315 Squadron, b.m., b.d., 1-10; AIR-27-1701-14, No. 315 Squadron, b.m., b.d., 1-10; Pilot's Flying Log Book: Jakub Bargiełowski; Pilot's Flying Log Book: Bożydar Nowosielski; Pilot's Flying Log Book: Michał Cwynar; Pilot's Flying Log Book: Kazimierz Kijak; Pilot's Flying Log Book: Henryk Pietrzak; Pilot's Flying Log Book: Tadeusz Słoń; Pilot’s Flying Log Book: Tadeusz Tamowicz; Pilot's Flying Log Book: Kazimierz Wünsche.

157 Matusiak, Gretzyngier i Wiśniewski, 315, 109, 112. 


\section{Bibliografia}

\section{Archiwalia}

The National Archives Kew

Combat Reports

Operation Record Books

Instytut Polski i Muzeum im. gen. Sikorskiego

315 Dywizjon Myśliwski

Dowództwo Polskich Sił Powietrznych

\section{Książki lotów pilotów}

Pilot's Flying Log Book, Bargiełowski Jakub, w zbiorach autora.

Pilot's Flying Log Book, Bożydar Nowosielski, w zbiorach autora.

Pilot's Flying Log Book, Cwynar Michał, w zbiorach autora.

Pilot's Flying Log Book, Kijak Kazimierz, w zbiorach autora.

Pilot's Flying Log Book, Pietrzak Henryk, w zbiorach autora.

Pilot's Flying Log Book, Słoń Tadeusz, w zbiorach autora.

Pilot's Flying Log Book, Tamowicz Tadeusz, w zbiorach autora.

Pilot's Flying Log Book, Wünsche Kazimierz, w zbiorach autora.

\section{Wspomnienia}

Bargiełowski, Jakub. Mustangiem w polu ognia. Warszawa: Stowarzyszenie Lotników Polskich, 2010.

Cwynar, Michał. Wspomnienia wojenne. Warszawa: Michał Cwynar \& Wojtek Matusiak, 2004.

Hamlin, Paul, i Ann Davies. Coolham airfield remembered. Memories and anecdotes of a Sussex D-Day Fighter Station and Village. Horsham: Paul Hamlin, 1996.

Kijak, Kazimierz i Alan Scheckenbach. The Quiet One. Canberra: b.w., 2008.

\section{Opracowania}

Brown, Alan. Airmen in Exile. The Allied Air Forces in the Second World War. Phoenix Mill-Thrupp-Stroud: Sutton Publishing Ltd., 2000.

Copp, Terry. The Brigade: The Fifth Canadian Infantry Brigade in World War II. Machanicsburg: Stackpole Books, 2007.

Cumft, Olgierd i Hubert Kazimierz Kujawa. Księga lotników polskich poległych zmarłych i zaginionych 1939-1946. Warszawa: Wyd. Ministerstwa Obrony Narodowej, 1989.

Cynk, Jerzy Bogdan. „Polskie lotnictwo inwazyjne.” Skrzydlata Polska, nr 6 (1994), 46-52.

Cynk, Jerzy Bogdan. Polskie Siły Powietrzne w wojnie 1939-1943. T. 1-2. Gdańsk: Wyd. Aj-Press, 2001-2002.

Gabszewicz, Aleksander Klemens i Zygmunt Witymir Bieńkowski. „Lotnictwo Myśliwskie 2. TAF.” Lotnictwo Aviation International, nr 15 (1992), 38-40.

Gabszewicz, Aleksander Klemens i Zygmunt Witymir Bieńkowski. „Lotnictwo Myśliwskie 2. TAF (część 2).” Lotnictwo Aviation International, nr 16 (1992), 31-33.

Grabowski, Franciszek. „D+1, wielki dzień 133 Skrzydła.” Magazyn Historyczny „Militaria i fakty" 8, nr 2 (2007). 
Grabowski, Franciszek. „D+1, wielki dzień 133 Skrzydła (część 2).” Magazyn Historyczny „Militaria i fakty” 8, nr 4 (2007), 4-12.

Gretzyngier, Robert. 307 Dywizjon Myśliwski Nocny „Lwowskich Puchaczy”. Warszawa: Bellona, 2006.

Gretzyngier, Robert, Wojtek Matusiak, Waldemar Wójcik i Józef Zieliński. Ku czci poległych lotników 1939-1945. Warszawa: Agencja Lotnicza Altair, 2006.

Hamlin, Paul i Ann Davies. Coolham airfield remembered. Memories and anecdotes of a Sussex D-Day Fighter Station and Village. Horsham: Paul Hamlin, 1996.

Hodyra, Piotr. 301 Dywizjon Bombowy 1940-1943. Warszawa: Ofic. Wyd. Alma-press, 2016.

Jaśkiewicz, Łukasz. 300 Dywizjon Bombowy „Ziemi Mazowieckiej”. Oświęcim: Napoleon V, 2013.

Jaśkiewicz, Łukasz. 304 Dywizjon Bombowy „Ziemi Śląskiej im. Ks. Józefa Poniatowskiego". Oświęcim: Napoleon V, 2018.

Johnson, David C. U. S. Army Air Forces Continental Airfields (ETO) D-Day to V-E Day. Maxwell: Research Division USAF Historical Research Center, 1988.

Kalinowski, Franciszek. Lotnictwo Polskie w Wielkiej Brytanii. Paryż: Wyd. Instytut Literacki, 1969.

Kolacha, Zbigniew i Jacek B. Żurek. North American P-51 Mustang, P-82 Twin Mustang. (Część 2). Gdańsk: Wyd. Aj-Press, 1999.

Król, Wacław. Polskie skrzydła w inwazji na Francję. Warszawa: Wyd. Ministerstwa Obrony Narodowej, 1983.

Kutzner, Jacek. 303. Dywizjon Myśliwski w bitwie o Wielka Brytanię. Warszawa: Ofic. Wyd. Rytm, 2010.

Kutzner, Jacek. 308. Dywizjon Myśliwski „Krakowski”. Warszawa: Ofic. Wyd. Rytm, 2011.

Kutzner, Jacek. 315. Dywizjon Myśliwski „Dębliński”. Warszawa: Ofic. Wyd. Rytm, 2013. Matusiak, Wojtek. 306 Dywizjon Myśliwski Toruński. Warszawa: Bellona, 2003.

Matusiak, Wojtek. „Dziubek u Kosynierów (część 2).” Lotnictwo 9, nr 6 (2006), 60-64.

Matusiak, Wojtek. „Polskie formacje lotnicze w inwazji na Normandię.” Biuletyn IPN, nr 6 (2019): 89-101.

Matusiak, Wojtek, Robert Gretzyngier i Piotr Wiśniewski. 315 Squadron (Polish) Squadron „Dęblin”. Tłum. Wojtek Matusiak. Sandomierz: Stratus, 2004.

Moor, Anthony John. Mustang Wing. RAF Brenzett Advanced Landing Ground. Romney Marsh, Kent 1942-1944. St-Leonards-on-Sea: HPC Publishing, 1999.

Passmore, David G, David Capps Tunwell i Stephan Harrison. „Landscapes of Logistics: The Archaeology and Geography of WWII German Military Supply Depots in Central Normandy, North-west France." Journal of conflict Archeology 8, nr 3, (2013): 165-92.

Przybył, Jacek. „Mustang i szachownica. Zarys działań wojennych 133. Skrzydła Myśliwskiego." Technika Wojskowa Historia, nr 4 (2012), 52-65.

Rowley, Clive. D-Day RAF. The Raf's part in the great invasion. Horncastle: Mortons Media Group Ltd., 2014.

Shores, Christopher i Chris Thomas. 2nd Tactical Air Force. Volume one Spartan to Normandy June 1943 to June 1944. T. 1. Horsham: Classic Publications an imprint of Ian Allan Publishing Ltd., 2004. 
Shores, Christopher i Clive Williams. Aces High. A Tribute to the Most Notable Fighter Pilots of the British and Commonwealth Forces in WWII. London: Grub Street, 1994. Sikora, Piotr. Bitwy polskiego lotnictwa 1918-1945. Warszawa: Ofic. Wyd. Alma-press, 2016.

Sojda, Grzegorz, Grzegorz Śliżewski i Piotr Hodyra. Ci cholerni Polacy! Polskie Sity Powietrzne w Bitwie o Anglię. Warszawa: Ofic. Wyd. Alma-press, 2016.

Śliżewski, Grzegorz. Nad krwawiącymi liśćmi klonu. Polscy piloci myśliwscy w operacji „Jubilee” (Dieppe, 19 sierpnia 1942 roku). Oświęcim: Napoleon V, 2018.

Śliżewski, Grzegorz. Wojna na pociski i pisma. 302 „Poznański” Dywizjon Myśliwski w 1940 roku. Oświęcim: Napoleon V, 2019.

Śliżewski, Grzegorz i Sojda. Cyrk Skalskiego. Piekary Śląskie-Warszawa: Wyd. ZP Grupa, 2009.

Wroński, Marek i Rafał E. Stolarski. Waleczne „Kubusie”. Monografia 663 Dywizjonu samolotów artylerii. T. 1-2. Londyn-Tarnowskie Góry: Wyd. Instytutu Tarnogórskiego, 1999.

Yung, Christopher D. Gators of Neptune. Naval Amphibious planning for the Normandy Invasion. Annapolis: Naval Institute Press, 2006.

Zieliński, Józef. 303 Dywizjon Myśliwski Warszawski im. Tadeusza Kościuszki. Warszawa: Bellona, 2003.

Zieliński, Józef. 305 Dywizjon Bombowy Ziemi Wielkopolskiej i Lidzkiej im. Marszałka Józefa Piłsudskiego. Warszawa: Bellona, 2004.

Zieliński, Józef. 663. Dywizjon Samolotów Artylerii. Warszawa: Wyd. Lampart, 2000.

Zieliński, Józef i Tadeusz Krzystek, Dowódcy dywizjonów Polskich Sit Powietrznych na Zachodzie. Tłum. Paulina Stęplowska. Poznań: Wyd. Redakcja Czasopism WLOP przy współpracy z Domem Wyd. Bellona, Poznań 2002.

\section{Internet}

Arsicaud, Thierry. „The Coordinates Translator.” Dostęp luty 20, 2021. http://www. echodelta.net/mbs/eng-translator.php

Ratuszyński, Wilhelm. „25 May.” Polish Squadrons Remembered. Dostęp styczeń 25, 2021. http://polishsquadronsremembered.com/315/44/may_25_44.html

Youngs, Kelvin. „19.04.1944 No. 315 Squadron Mustang III FX895 P/O. Brygider.” Aircrew Remembered. Dostęp styczeń 25, 2021. http://aircrewremembered.com/ brygider-roman.html

Zmyślony, Wojciech. „Zbigniew Czaykowski.” Polskie Siły Powietrzne w II wojnie światowej. Dostęp maj 8, 2021. https://www.polishairforce.pl/czaykowski.html

\section{STRESZCZENIE}

Marcin Arbuz, Działania bojowe 315 Dywizjonu Myśliwskiego „Dęblińskiego” podczas operacji „Overlord” 6 czerwca - 7 lipca 1944 r.

Artykuł ukazuje przebieg udziału 315 Dywizjonu Myśliwskiego „Dęblińskiego” w operacji „Overlord”. Jednostka włączona w struktury 2 Tactical Air Force prowadziła działania bojowe nad Normandią w ramach 133 Skrzydła Myśliwskiego, 
skupiając się przede wszystkim na wsparciu wojsk lądowych poprzez atakowanie celów naziemnych w rejonie frontu lub na głębokim zapleczu przeciwnika. W pierwszej połowie lipca 1944 r. dywizjon został wyłączony ze struktury 2nd TAF i przeniesiony do składu Powietrznej Obrony Wielkiej Brytanii w celu przeciwdziałania niemieckim atakom prowadzonym przy użyciu latających bomb V1. 315 Dywizjon Myśliwski był jednym z pięciu dywizjonów myśliwskich Polskich Sił Powietrznych, bezpośrednio zaangażowanych w operację „Overlord”. Pomimo stosunkowo krótkiej obecności w strukturach 2nd TAF, wniósł istotny wkład w ostateczne powodzenie całej operacji.

Słowa kluczowe: Overlord, inwazja w Normandii, D-Day, 315 Dywizjon Myśliwski, 133 Skrzydło Myśliwskie, 2nd Tactical Air Force

\section{SUMMARY}

\section{Marcin Arbuz, The combat Missions of No. 315 Squadron (Dęblin) during Operation "Overlord” - 6 June - 7 July 1944}

The article describes the role of No. 315 Squadron (Dęblin) during Operation "Overlord". The unit, which was assigned to No. 133 Wing of the 2nd Tactical Air Force (2nd TAF) was primarily deployed in a close air support role over Normandy, focusing mainly on enemy targets in both front-line area and deep behind enemy lines. In the first half of July 1944 the squadron was transferred from the 2nd TAF to the Air Defence of Great Britain command, in order to counteract the threat posed by German V-1 "flying bombs". No. 315 Squadron was one of five Polish Air Force fighter squadrons directly involved in Operation "Overlord", and despite its relatively short presence within the 2 nd TAF structure the unit played a crucial role with regards to the overall success of the entire operation.

Keywords: Overlord, Normandy landings, D-Day, 315 Squadron, 133 Wing, 2nd Tactical Air Force

\section{АННОТАЦИЯ}

\section{Марчин Арбуз, Боевые действия 315-й истребительной эскадрильи „Демблинской” в ходе операции „Оверлорд” - 6 июня - 7 июля 1944 года}

В статье показано участие 315-й истребительной эскадрильи „Демблинской” в операции „Оверлорд”. Подразделение, входящее в состав 2-й тактической авиации, вело боевые действия над Нормандией в составе 133-го истребительного авиакрыла, уделяя основное внимание поддержке сухопутных войск путем нанесения ударов по наземным целям в районе фронта или на территории противника. В первой половине июля 1944 г. эскадрилья была 
исключена из состава 2-ой тактической авиации и передана в состав воздушных сил Великобритании для противодействия немецким атакам с помощью летающих бомб V1. 315-я истребительная эскадрилья была одной из пяти истребительных эскадрилий польских ВВС, принимавших непосредственное участие в операции „Оверлорд”. Несмотря на относительно короткое присутствие в структурах 2-й тактической авицации, она внесла значительный вклад в окончательный успех всей операции.

Ключевые слова: Оверлорд, вторжение в Нормандии, День Д, 315-я истребительная эскадрилья, 133-й истребительное авиакрыло, 2-я тактическая авиация 